\title{
Dynamics and Origin of Saline Soils on the Slims River Delta, Kluane National Park, Yukon Territory
}

\author{
STUART A. HARRIS
}

(Received 16 January 1989; accepted in revised form 20 November 1989)

\begin{abstract}
The saline soils of the Slims River Delta have developed on land formed in the last 100 years in an area of otherwise continuous permafrost. Deep seasonal frost on the delta prevents downward leaching of salts when the snow melts. Instead the salts accumulate at the surface as the ground dries, while additional salts are added from springs at the base of the surrounding mountains. Late summer rains can leach the soils if they are sufficiently heavy, producing a three- to fourfold variation in salinity from year to year.

The efflorescences are dominated by the hexahydrate of magnesium sulfate, and the high sulfate content is probably the reason that soils in depressions with the morphology of solonetzic soils remain reasonably friable. The distribution of the characteristic halophytic plant associations found on these soils appears to be controlled more by soil moisture content than by the actual salinity level.
\end{abstract}

Key words: saline soils, salinity, seasonal frost, solonetz, solonchak

RÉSUMÉ. Les sols salins du delta de la rivière Slims se sont développés sur un terrain qui s'est formé au cours du dernier siècle, dans un région où avait toujours sévi le pergélisol. Le gel saisonnier en profondeur dans le delta empêche le lessivage vertical des sels quand la neige fond. Ces sels s'accumulent donc à la surface au fur et à mesure que le sol sèche, et il s'y ajoute des sels provenant de sources situées au pied des montagnes environnantes. Les pluies de la fin de l'été peuvent lessiver les sols si elles sont assez abondantes, ce qui résulte en une variation de la salinité du sol, allant au triple ou au quadruple, d'une année à l'autre.

Les efflorescences sont dominées par l'hexahydrite de sulfate de magnésium, et la teneur élevée en sulfate est probablement la raison pour laquelle les sols restent relativement friables dans les dépressions dont le sol est morphologiquement semblable à un solonetz. Sur ces sols, la distribution des associations de plantes halophiles types semble être contrôlée plus par le taux d'humidité du sol que par le taux de salinité présent.

Mots clés: sols salins, salinité, gel saisonnier, solonetz, solontchak

Traduit pour le journal par Nésida Loyer.

\section{INTRODUCTION}

The term "saline soils" is used in this paper to refer to soils that contain a high concentration of soluble salts. They are normally recognized by a white encrustation or efflorescence on the ground surface when the soils are dry and by an electrical conductivity greater than $4 \mathrm{mS} / \mathrm{cm}$ at $25^{\circ} \mathrm{C}$ (USDA, 1954). The natural vegetation usually consists of salt-tolerant species.

Saline soils may occur in the tropics, where frost is absent (e.g., Raychaudhuri and Murthy, 1960; Horn et al., 1967; Sokolovskiy, 1967; El'Swaify et al., 1983), in areas with varying degrees of seasonal frost (e.g., Ballantyne, 1978; Johnson et al., 1985), through to areas of continuous permafrost (e.g., Rieger, 1983; Ugolini, 1986). Obviously the saline soils of tropical areas form without any influence of frost, in contrast to those of permafrost regions, where the influence of essentially impermeable frozen layers has been shown to have a marked effect on the accumulation, distribution and temporal variations in soil salinity (see Elovskaya, 1964).

Surprisingly, an examination of the literature reveals that there have been virtually no studies outside the Soviet Union of the role of seasonal frost in aiding the accumulation of soil salinity. This paper examines the dynamics and origin of the saline soils on the young Slims River Delta in Kluane National Park, southwest Yukon Territory, where deep seasonal frost appears to be a major factor influencing their development.

\section{STUDY AREA}

Figure 1 shows the location of the study area, which lies on the Slims River Delta at the southeastern end of Kluane Lake, Yukon Territory. The saline soils appear as a complex light-

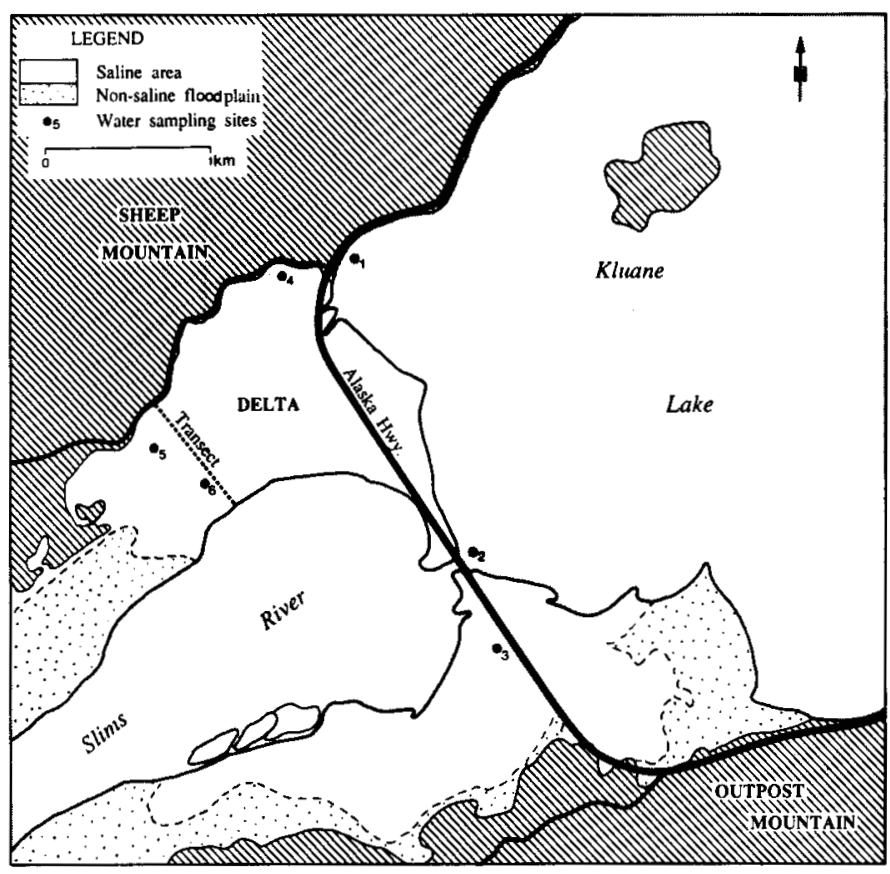

FIG 1. Location of the study area.

coloured pattern on aerial photographs taken in late summer. The area lies in the rain shadow of the St. Elias Range on the northern boundary of Kluane National Park.

The Slims River is $22.5 \mathrm{~km}$ long and flows as a braided stream in a valley $1830 \mathrm{~m}$ wide (Fahnestock, 1969). Four major fans constrict the valley just above the delta. Discharge varies from zero in winter to $566.3 \mathrm{~m}^{3} / \mathrm{sec}$ in late summer 
(Fahnestock, 1969), but this flow regime can also be modified by unpredictable shifts in the meltwater draining from the Kaskawulsh Glacier from the Slims River to the Kaskawulsh River (Barnett, 1971). There are both seasonal (Fig. 2) and diurnal fluctuations in water flow.

Progradation of the Slims River Delta was an average of $17.7 \mathrm{~m} / \mathrm{yr}$ between 1944 and 1974 (Bryan, 1974), although the exact rate of growth is difficult to measure due to the fluctuating lake levels. Water conductivity in the Slims River is higher than in the other rivers tested (Foothills Pipelines, 1976), the water having an electrical conductivity of 180-425 $\mu \mathrm{S} / \mathrm{cm}$. However, this is not exceptionally high and varies seasonally (Barnett, 1971). Maximum salinities are encountered in the early spring and in late summer during periods of reduced flow (Fig. 2).

A series of small springs occurs on the delta surface below the base of the valley walls where groundwater comes to the surface under artesian pressure. The surrounding mountains exhibit continuous permafrost (Harris, 1983, 1987), and the springs may represent superglacial, intraglacial or subglacial groundwater flow.

The nearest long-term climatic station is at Haines Junction, where the mean annual temperature for 1951-80 was $-3.2^{\circ} \mathrm{C}$ (Fig. 3). Mean monthly precipitation for the same period varied fron $7.9 \mathrm{~mm}$ in April to $36.3 \mathrm{~mm}$ in July (Canada Department of Environment, 1982). Snow may occur in any month of the year but is the predominant form of precipitation from October to April.

More than 18 hours of solar radiation are received at this latitude at the summer solstice, so that theoretically, at that time of year, total insolation per day on a horizontal surface shows little variation polewards of $55^{\circ}$ latitude (Johnston, 1981). Potential evapotranspiration can be considerable in May and June (Wahl et al., 1987:Table 11.6), aided by the dry, down-valley Chinook winds (Nickling, 1976).

\section{METHODS}

The area was intensively studied each summer from 1985 to 1988 . First, an $870 \mathrm{~m}$ transect was selected from the Bullion Creek access road eastwards to the channel of the Slims River. It was chosen so as to include low spots with ponding in the spring, high spots with salt efflorescences, and a full range from maximum vegetation cover to barren areas. The soils ranged from saline ( $>4 \mathrm{mS} / \mathrm{cm}$ electrical conductivity) to nonsaline soil. A leveling survey was carried out along this transect so that data could be related to the topography.

Eight access tubes were emplaced at roughly $100 \mathrm{~m}$ intervals along the transect in May 1985, so that ground temperatures could be monitored without disturbing the ground in subsequent years. Drilling was accomplished by a cold-water jet drill that thawed a hole through the layers of ice to a depth of 2-3.5 m. Thermistor cables were constructed using YSI 44033 thermistors at $25 \mathrm{~cm}$ intervals beneath the surface and $50 \mathrm{~cm}$ intervals below $1.5 \mathrm{~m}$. These were augmented with $1 \mathrm{~m}$ strings of calibrated transistors with a spacing of $10 \mathrm{~cm}$ to provide more detail of the temperature changes in the surface horizons. These transistors functioned for only two years, whereas the thermistors were still in good working order when removed at the end of the field work. Temperature readings were made on a weekly basis for the summers (May
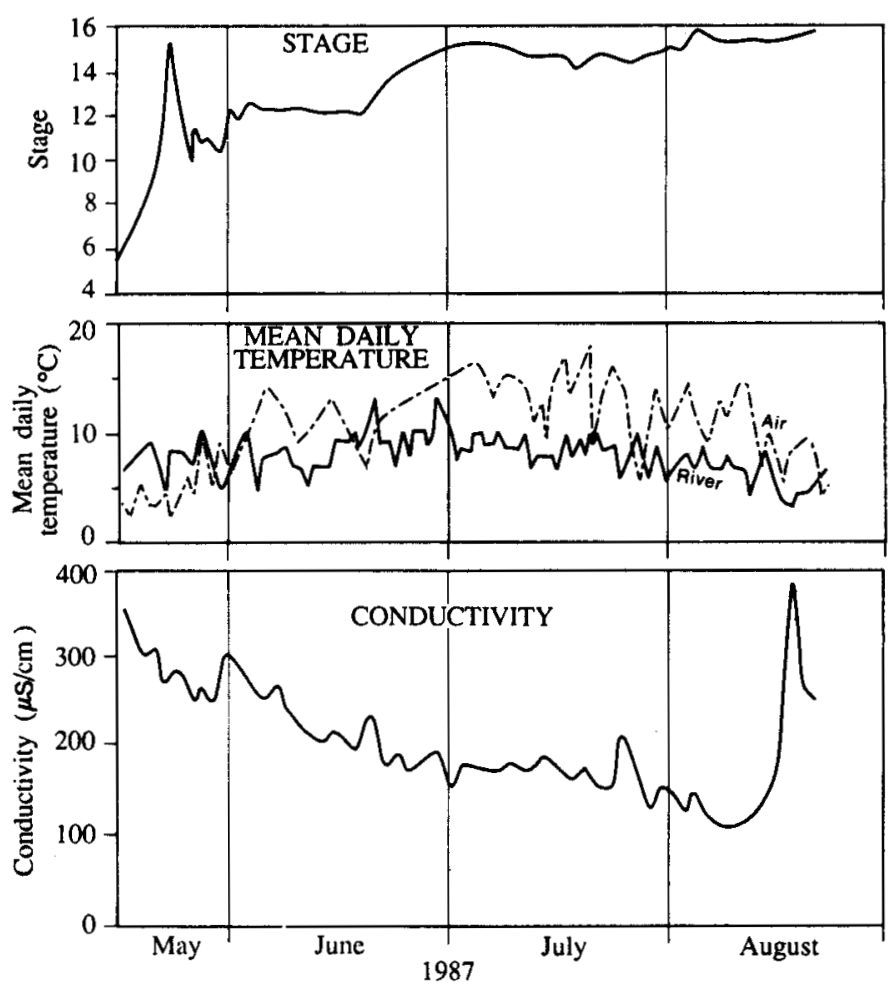

FIG. 2. Variation in level of the Slims River in relation to the mean daily air temperature and to conductivity of river water $(\mu \mathrm{S} / \mathrm{cm})$ during the summer of 1987.

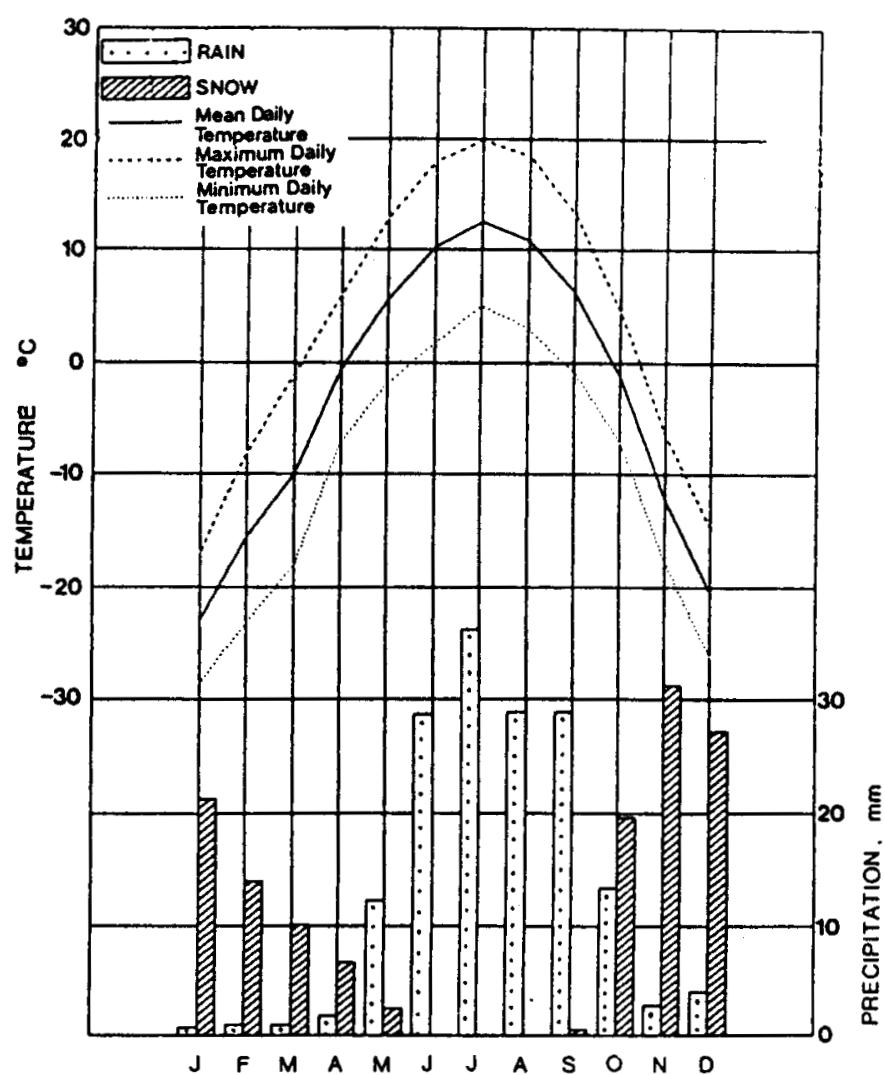

FIG. 3. Mean climatic data for 1951-80 for Haines Junction (Canada Department of Environment, 1982). 
to August inclusive) from June 1985 until 20 August 1987. Where possible, winter readings were also obtained.

Groundwater levels were monitored using capped PVC piezometer tubes installed by drilling to between $85 \mathrm{~cm}$ and $2 \mathrm{~m}$ at each site. The bottom of the piezometer tube was sealed and saw cuts were made in the lower $45 \mathrm{~cm}$ to permit inflow of any groundwater. Later, shallower piezometer tubes were added to monitor perched water tables. Again, weekly measurements were obtained of the water level, if any, in each tube.

Twenty-five soil sampling sites were designated along the transect so that repeated soil sampling could be carried out to assess the level of salinity and its seasonal variations with topographic position, soil moisture and the position of any seasonal frost. Soil samples were collected once a week using a hand auger, sampling the soil at $5,30,60$ and $90 \mathrm{~cm}$, or to the frost table, whichever was shallower. This allowed confirmation of the results of the ground temperature data. At Kluane Lake Research Station (of the Arctic Institute of North America), they were air dried and then salinity was measured in a 1:4, soil:water solution using a Hach Model 16300 portable conductivity meter and solutions of standard concentration (USDA, 1954; Rhoades, 1976).

Samples were also collected of the salt efflorescence on the soil surface for X-ray diffraction in the Geology Department, University of Calgary. Following problems with change in hydration during storage, all the later samples were sprayed with a clear plastic coating (Krylon) to prevent transformation.

Typical soil profiles were examined and described in pits dug approximately $10 \mathrm{~m} \mathrm{ENE}$ of the temperature monitoring sites. These included the main variations in the soils on the delta, and samples were collected for particle size and conductivity analysis. The particle analysis was carried out in the laboratories of the Geography Department, University of Calgary, using the pipette method of Kilmer and Alexander (1949). Calgon was used as the dispersant after treatment with hydrogen peroxide.

Water samples were collected from the groundwater in the piezometer tubes from springs at the foot of Sheep Mountain, from Kluane Lake, and from the Slims River. These were submitted to the Environment Canada water analysis laboratory in Vancouver for analysis (see Appendix A for methods used), and additional samples were analyzed by Dr. A.A. Levinson at the Geology Department, University of Calgary.

In July 1986 and 1987, the distribution of salinity in the surface soils was mapped on the west side of the river using a $100 \mathrm{~m}$ grid, with soil samples being collected at 10 and $20 \mathrm{~cm}$ depths at each grid point. This allowed a study to be carried out of the variability of the salinity over a large area of the west side of the delta in these two summers.

The plant communities present were identified by repeated visual inspections along the transect in 1985. A detailed description was made of the variations in vegetation, including species composition, abundance and percentage cover. Where these changed markedly, a community boundary was identified. Plots $2 \times 2 \mathrm{~m}$ in size and spaced $15 \mathrm{~m}$ apart along the transect were utilized, together with additional plots drawn from a table of random numbers. The majority of the species were in the herbaceous layer, exceptions including Populus balsamifera and Salix spp. Each community was given a floristic name describing the dominant or co-dominant species, the dominant species being defined as the one that occupied the most space based on the cover-abundance estimate. Specimens of the plants were collected, pressed and dried, and the species determined in the herbarium of the Department of Biology, University of Calgary. The species of Salix were identified by Dr. G.W. Argus, National Museums of Canada, Ottawa. The grasses were identified by Mrs. K.H. Wilkinson, and for a selection of critical examples the identifications were confirmed by the Department of Agriculture, Ottawa.

Finally, samples were taken of the soil in the rooting zone of the various plant species on the delta so as to determine the salinity tolerances of each species. The salinity of these soil samples was determined in the same manner as that of the weekly samples from the soil sampling sites, while the moisture content at the time of sampling was determined gravimetrically.

\section{RESULTS FROM THE TRANSECT}

\section{Topography and Stratigraphy}

The cross-section (Fig. 4A) shows that the delta has a gently undulating surface with a general slope towards the river. The depressions originated partly as old distributary channels and partly by wind erosion (see Nickling, 1976, 1978). They are undergoing further modification by wind action, congelifluction as the snow cover thaws in the spring and slope wash as the meltwater drains to the river channel. All these processes are operating on the upper silty layer of
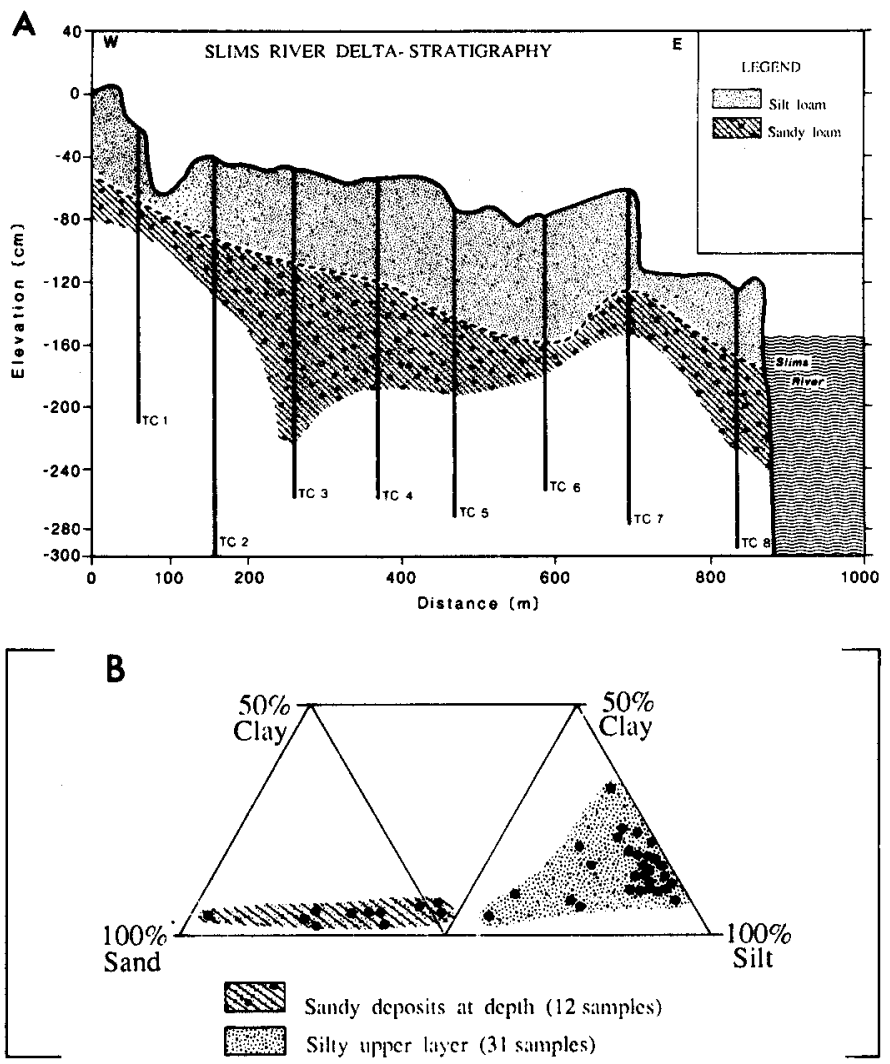

FIG. 4. A) Topography and stratigraphy along the transect across the west side of the Slims River Delta. B) Grain size of the sediments. 
overbank or backswamp deposits, which are underlain by a thick, coarser sandy loam. The latter probably represents a combination of stream channel and foreset beds, although no bedding could be discerned in them. The same stratigraphy occurred throughout the transect. Figure $4 \mathrm{~B}$ also shows the particle size of the samples collected from the drill holes based on the USDA particle size limits $(2.0-0.05 \mathrm{~mm}$ sand, 0.05-0.002 mm silt, <0.002 mm clay).

\section{Soil Temperatures}

Figure 5 shows the results of measuring soil temperatures during the spring and summer of 1986. By then, the thermal effects of drilling the holes for the access tubes had long since dissipated, and the results are typical of the other years. In early May (Fig. 5A), runoff from Sheep Mountain had caused some thawing at the western end of the transect, while there was also some moderate thawing of the soil accompanied by erosion from melted snow near the Slims River. Elsewhere, the meltwater had turned the surface into a sea of mud, and congelifluction was occurring. Within a few days, the surface was drying, especially on the ridges, and the thawing front was moving downwards (Fig. 5B). By mid-June, thawing from above and below had reduced the seasonally frozen ground to a zone about $70 \mathrm{~cm}$ thick, which underlay the whole of the transect except at the river bank (Fig. 5C). By mid-July, this seasonally frozen ground had largely thawed (Fig. 5D), and thereafter there was no obvious barrier to downward percolation of soil water. Surface soil temperatures had risen to $20^{\circ} \mathrm{C}$ on the ridges, so that potential evapotranspiration rates would be high for the rest of the summer.

During the winter, the snow cover was found to be quite thin, since the northerly winds blowing across the frozen lake tended to remove the snow (Fig. 6). As a result, the upper layers of soil were very cold, and by mid-February the freezing front had reached $1.8 \mathrm{~m}$ depth. This pattern occurred each year, so that the delta was always frozen to a depth of 3-4 m by the end of April.

\section{Water Table}

The piezometer tubes generally did not show the presence of a water table within the upper $1.0 \mathrm{~m}$ of the soil. It appears that the sandy deposits permit free drainage of the water into the river and the lake.

Two exceptions occurred. First, when the ground was thawing in the spring, a shallow perched water table was
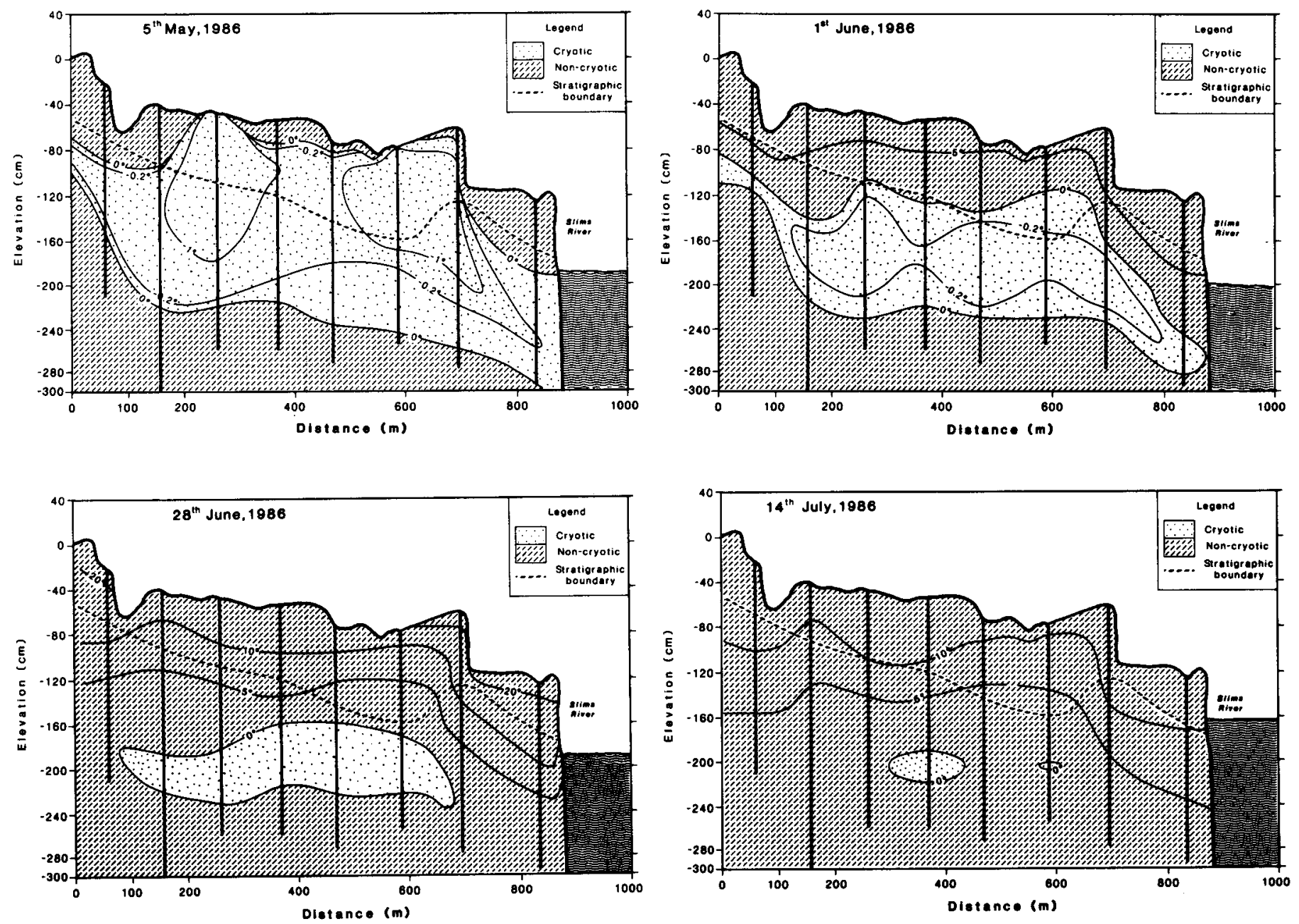

FIG. 5. Ground temperatures during the spring and early summer along the transect in 1986. 
generally found above the thawing front. Below this seasonal frost, the water table was absent. Second, the groundwater entered the piezometers located within about $400 \mathrm{~m}$ of the river from below at the end of the summer when the river stage was high enough.

\section{Salinity}

Figure 7 shows the pattern of salinity in relation to the distribution of the seasonal frost and the topography for the transect during the spring and summer of 1986. At the beginning of May (Fig. 7A), some surface salinity could be demonstrated on the ridges, but water from the melting snow had produced a diluted soil paste above the water table. This muddy surface layer quickly dried as the thawing front descended, and the salts moved up to the surface of the soil, presumably in response to evaporation (Figs. 7A,B,C,D). This process continued until the seasonal frost layer ceased to form a continuous layer at depth in late June (Fig. 7E). Thereafter, the surface conductivities tended to become less extreme as the July rains caused the salts to become more widespread through the soil profiles (Figs. $7 E, F, G, H$ ). However, the rains were insufficient to flush the salts out of the surface soils to any extent except in 1988.

Considerable variation was seen in the degree of salinity from year to year, as can be shown by plotting the data for four different sites for three consecutive years (Fig. 8). The summer of 1985 provided relatively low values, so that although saline soils could be found, a considerable proportion of the transect would be classified as marginally saline. In 1986, the values at the same sites were much higher and showed quite a different seasonal pattern. In 1987, the values increased even more on the ridge-top sites, whereas the other sites were more like those for 1986. In 1988, heavy July precipitation resulted in lower values than in 1985 throughout the transect, presumably due to downward leaching of the soluble salts.

The increase in salinity on the ridge tops was fourfold between 1985 and 1987. This variability means that sampling saline areas for soil mapping using conductivity measurements needs to be carried out in the shortest possible time, and the mapping must be related to the cycle of seasonal and yearly variations demonstrated by repeated sampling, as in Figure 8.

\section{RESULTS OF SALINITY MAPPING}

Two attempts were made to map the salinity of the surface soils over a large area of the delta. The first was carried out in 1986 and the work was repeated in 1987 to check the variability in surface salinity of the same area from year to year (Figs. $9,10)$. In both years, high salinity at $10 \mathrm{~cm}$ depth in August was widespread, whereas salinities were lower at $20 \mathrm{~cm}$ depth. However, the progressive build-up of salts noted in Figure 8 was again verv obvious. A series of five years without heavy rains in July would undoubtedly result in the soils throughout most of the area being highly saline.

Comparison of Figures 9 and 10 indicates that the loci of areas of high salinity varies from year to year. The delta ridges always show higher salinity, but the areas of intermediate topography show fluctuating values. The exact reason for this is unclear, but factors involved may include changes in the location of springs, fluctuations in flow and salinity in

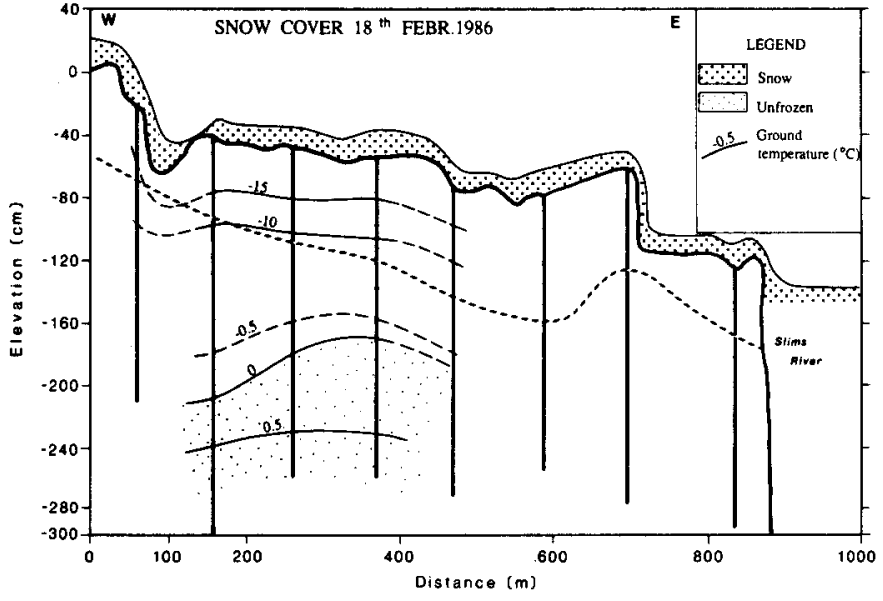

FIG. 6. Ground temperatures and snow cover along the transect on 18 February 1986.

springs, variations in snow cover and location from year to year, and changes in topography due to wind erosion, congelifluction and water erosion.

\section{RELATIONSHIP TO THE VEGETATION COVER}

Hoefs et al. (1975) found a very varied flora on the slopes of Sheep Mountain due west of the delta, while this author (Harris) and his students have identified over 120 species on the slopes of Outpost Mountain, immediately to the east. In spite of this, the general distribution of the saline soils can readily be recognized by the paucity of vegetation cover, low species diversity, or absence of vegetation altogether.

The vegetation of the saline area was chiefly herbaceous, exceptions being Populus balsamifera (tree layer, 2-9 $\mathrm{m}$ ) and scattered individuals of Salix alaxensis ssp. alaxensis and Salix brachycarpa ssp. niphoclada that formed a shrub layer $(90 \mathrm{~cm}$ to $2 \mathrm{~m}$ ). The results of the $2 \times 2$ plots indicated that seven plant communities occurred together with barren areas.

The most abundant community (17 out of 66 plots, or $37 \%$ ) was the Aster yukonensis/Deschampsia caespitosa community (Table 1). This and the Deschampsia caespitosa/Aster yukonensis community (Table 2) accounted for 28 of the 46 plots (61\%) studied. A similar community (Order 1: Puccinellio-Salicornietalia; Alliance 2: Deschampsion caespitosae; Association 4: Astero (yukonensis) - Deschampsietum caespitosae) was recognized by Hoefs $e t$ al. (1975). Another significant group was the Triglochin palustris/Puccinellia nuttalliana community (Table 3 ), which is undoubtedly a similar association not recognized by Hoefs et al. (1975), as is the Puccinellia nuttalliana community (Table 4). Likewise, the Juncus articus/ Deschampsia caespitosa community (Table 5) and the Ranunculus cymbelaria community (Table 6) are probably of the same order. The remaining community not represented in the plots is the Populus balsamifera community, which normally consisted of isolated trees with no herbaceous layer.

In order to try to determine whether there were any environmental causes of these distinct communities, the soil moisture and electrical conductivity ranges of the soil in the rooting zone for each plant community are compared with data for the barren area in Table 7. Moisture content appears to be a major factor in determining the vegetation cover, 
overbank or backswamp deposits, which are underlain by a thick, coarser sandy loam. The latter probably represents a combination of stream channel and foreset beds, although no bedding could be discerned in them. The same stratigraphy occurred throughout the transect. Figure $4 \mathrm{~B}$ also shows the particle size of the samples collected from the drill holes based on the USDA particle size limits $(2.0-0.05 \mathrm{~mm}$ sand, $0.05-0.002 \mathrm{~mm}$ silt, $<0.002 \mathrm{~mm}$ clay).

\section{Soil Temperatures}

Figure 5 shows the results of measuring soil temperatures during the spring and summer of 1986. By then, the thermal effects of drilling the holes for the access tubes had long since dissipated, and the results are typical of the other years. In early May (Fig. 5A), runoff from Sheep Mountain had caused some thawing at the western end of the transect, while there was also some moderate thawing of the soil accompanied by erosion from melted snow near the Slims River. Elsewhere, the meltwater had turned the surface into a sea of mud, and congelifluction was occurring. Within a few days, the surface was drying, especially on the ridges, and the thawing front was moving downwards (Fig. 5B). By mid-June, thawing from above and below had reduced the seasonally frozen ground to a zone about $70 \mathrm{~cm}$ thick, which underlay the whole of the transect except at the river bank (Fig. 5C). By mid-July, this seasonally frozen ground had largely thawed (Fig. 5D), and thereafter there was no obvious barrier to downward percolation of soil water. Surface soil temperatures had risen to $20^{\circ} \mathrm{C}$ on the ridges, so that potential evapotranspiration rates would be high for the rest of the summer.

During the winter, the snow cover was found to be quite thin, since the northerly winds blowing across the frozen lake tended to remove the snow (Fig. 6). As a result, the upper layers of soil were very cold, and by mid-February the freezing front had reached $1.8 \mathrm{~m}$ depth. This pattern occurred each year, so that the delta was always frozen to a depth of 3-4 m by the end of April.

\section{Water Table}

The piezometer tubes generally did not show the presence of a water table within the upper $1.0 \mathrm{~m}$ of the soil. It appears that the sandy deposits permit free drainage of the water into the river and the lake.

Two exceptions occurred. First, when the ground was thawing in the spring, a shallow perched water table was
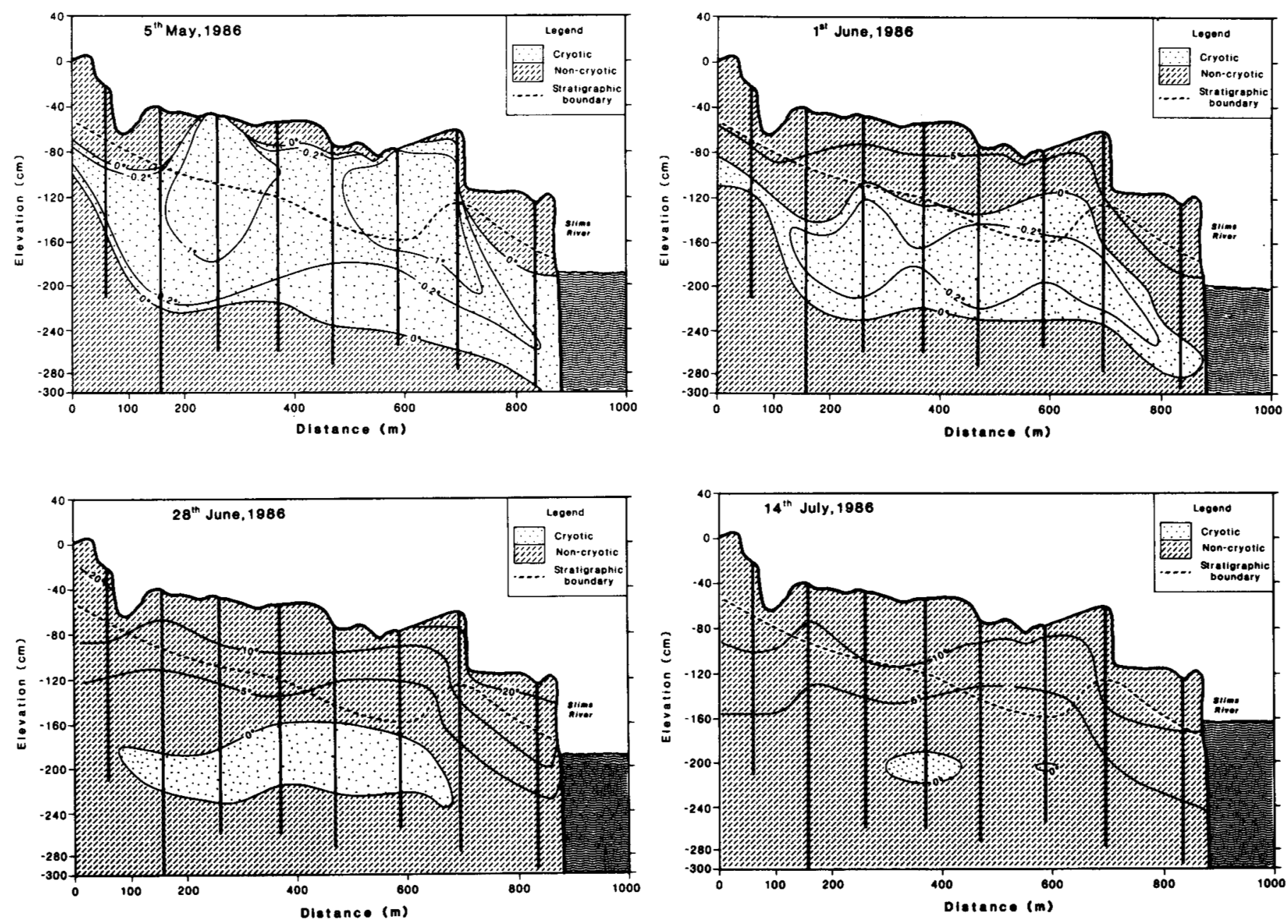

FIG. 5. Ground temperatures during the spring and early summer along the transect in 1986. 
collected along the transect. The Slims River water samples and those from Kluane Lake have the wrong $\mathrm{Ca}^{++}: \mathrm{Mg}^{++}$ratios to be an important source of the salinity.

The concentration of sodium and chloride ions in the pond is probably due to evaporation of water and precipitation of crystals of the soluble sodium and magnesium sulfates. This would be consistent with the mineralogy of the efflorescences discussed above.

It is noteworthy that the springs at the base of Sheep Mountain are more saline and have a lower flow than those at the base of Outpost Mountain on the east side of the river. The latter springs lie below a forested north-facing slope, while those below Sheep Mountain drain from a grassy south-facing slope. Thus the risk of salinization of lowlands is higher below the drier south-facing slopes in the southwestern Yukon Territory.

\section{NATURE OF THE SOILS}

The classification of saline soils is perhaps one of the areas where North American classifications differ most from those in some other parts of the world. This is probably because saline soils are not particularly widespread in North America (see the discussion of Salorthids in Soil Survey Staff, 1975), and "virtually no use is made of them" (Soil Survey Staff,
1975:177). In the Canadian Soil Classification, the saline soils only seem to be differentiated at the soil series level (Canada Soil Survey Committee, 1978), unless there has been sufficiently strong horizon differentiation and leaching to develop solonetzic soils or solods. Recently, McQuaid et al. (1987) have proposed that solodic soils be separated as a subgroup in the American system, but this still leaves the saline soils of humid or subhumid cool climates with no ready classification.

Originally, saline and alkali soils were classified as solonchaks, solonetz or solods (Glinka, 1931:428-465). This followed many systematic studies of the evolution of saline soils of high sodium chloride type that had been summarized by Sigmund (1928), and the earlier American soils classification in Baldwin et al. (1938) also followed this system. The solonchak was loosely defined as a soil profile with substantial accumulation of soluble salts in the surface horizons. The salinity decreased with depth, and the upper layers tended to exhibit a fine crumb structure and white efflorescence. The solonetz represented a profile where partial leaching at some seasons of the year had resulted in the development of prismatic cracking and an angular to subangular blocky structure. The profile may or may not be saline, but water and air penetration from the surface is impeded by the dense peds
$E$

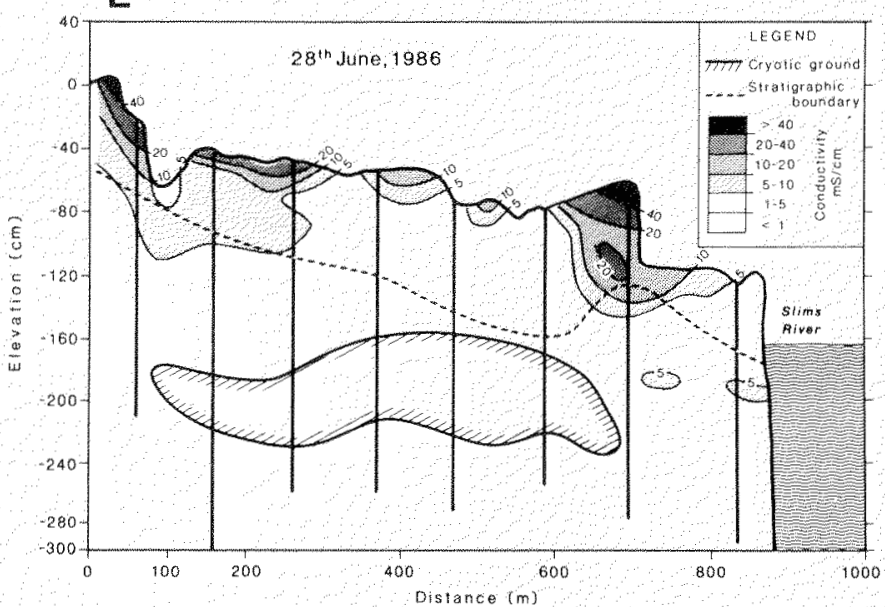

$G$

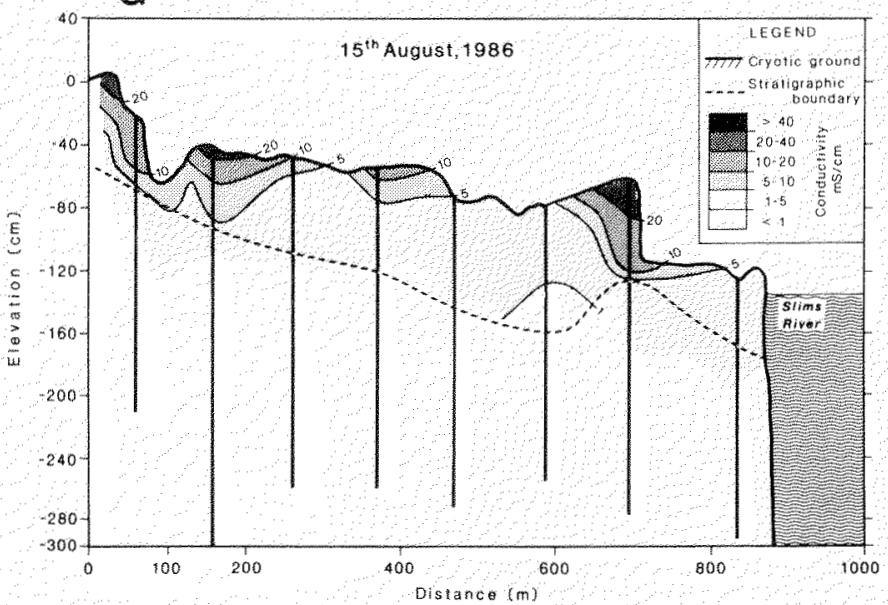

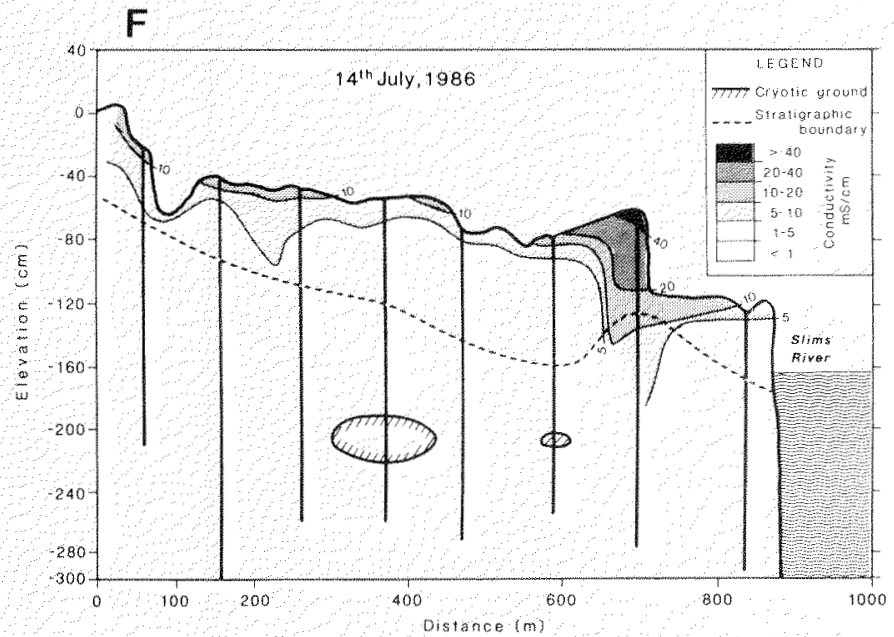

$H$

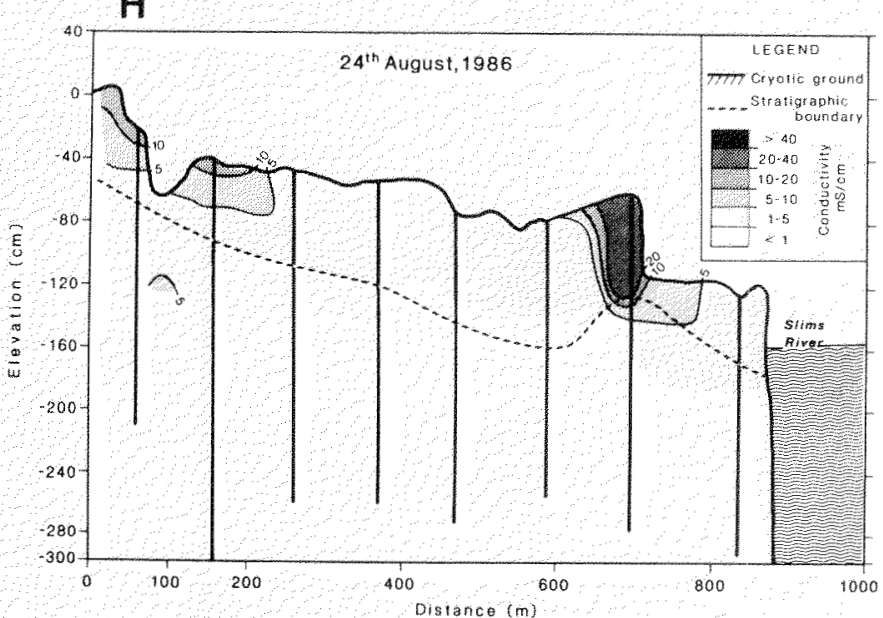

FIG. 7. (Continued) 

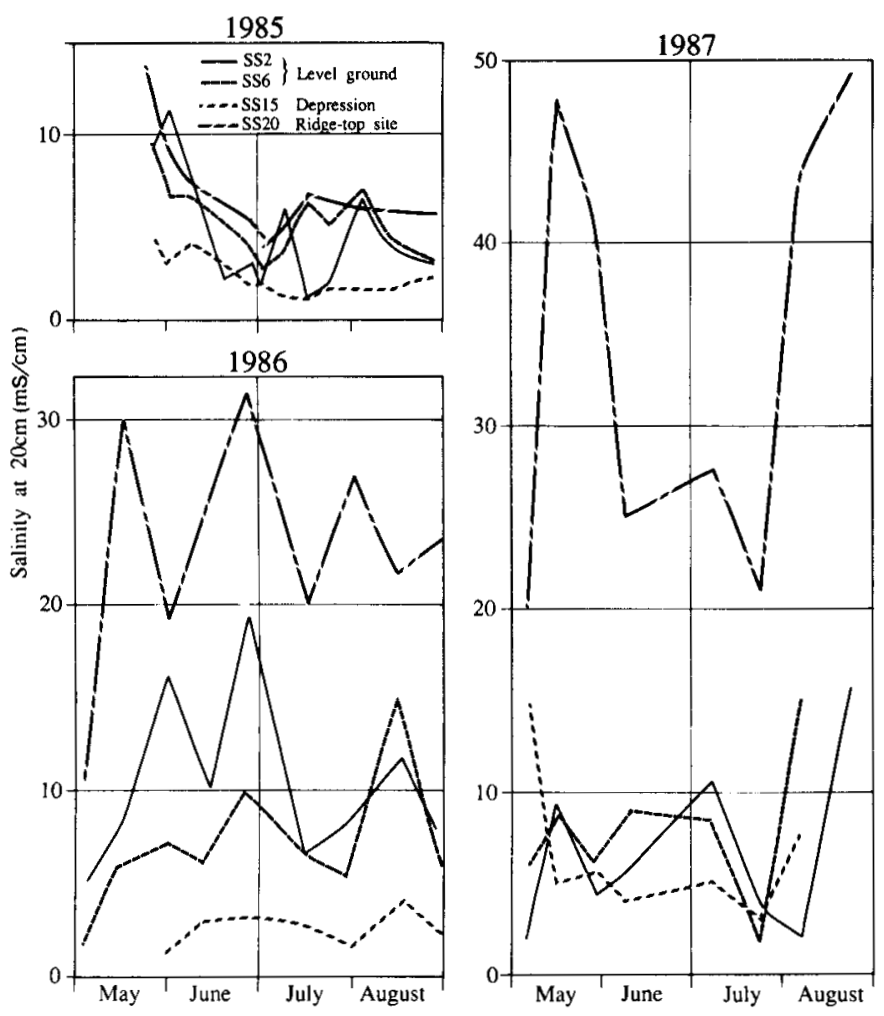

FIG. 8. Variation in salinity of the surface soil (at $20 \mathrm{~cm}$ depth) at four representative sites during three consecutive summers $(1985,1986,1987)$.

and poorer soil structure. Further leaching and deterioration of the structure were regarded as producing a solod. In extreme cases, gilgai may be produced (Hallsworth et al., 1955; Harris, 1958, 1959). These changes were accompanied by an unfavourable change in the exchangeable ions in the exchange complex of the clays, with sodium ions replacing calcium and magnesium ions.

This classification is introduced here because the saline soils on the Slims River Delta show many of the distinctive characteristics of the solonchaks of the older Eurasian soil classification systems. There are also weak solonetz profiles developed. Since the current North American classifications do not differentiate these, and the soils of the delta have not been mapped and assigned soil series names, the following description will use all three systems.

Eight soil pits were dug and described close to the sites of the ground temperature cables along the transect. Of these, one showed the beginnings of the development of saline soils, four showed good solonchak-type profiles and three showed weakly developed solonetz profiles.

The description of the profile showing the commencement of salinization on a new land surface is as follows:

\section{Pit TC \#8}

Soil developed on the Slims River floodplain alluvium on a new depositional surface, Kluane National Park - The delta is level and vegetation around the profile consisted of scattered Deschampsia caespitosa and Juncus arcticus covering $10 \%$ of the surface. A salt efflorescence coated the ground surface, while a seasonal frost table was encountered at $110 \mathrm{~cm}$.
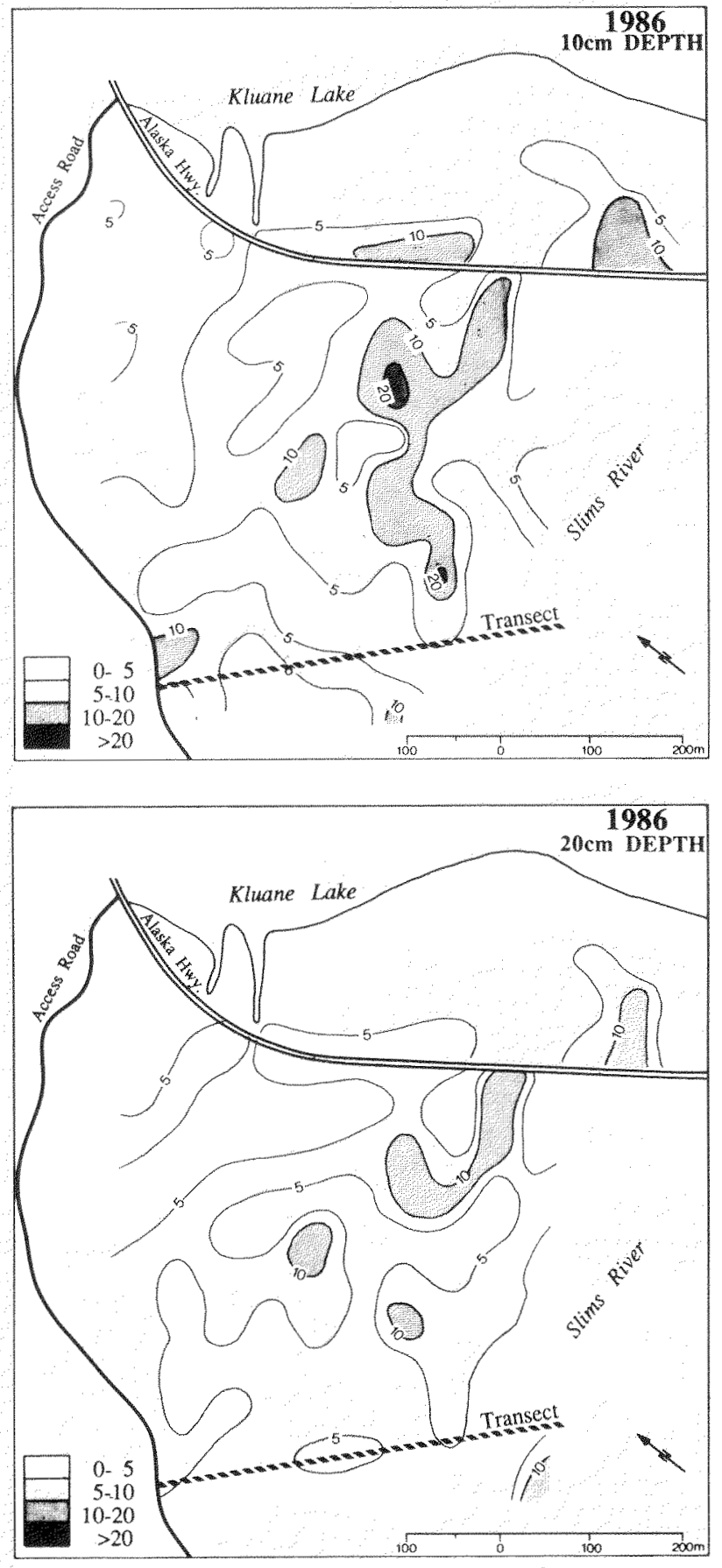

FG. 9. Distribution of salinity at $10 \mathrm{~cm}$ and $20 \mathrm{~cm}$ along a $100 \mathrm{~m}$ grid on the west side of the Slims River Delta on 16 August 1986.

$0-3 \mathrm{~cm}$

Csak

$3-25 \mathrm{~cm}$ Csakgj

$25-34 / 36 \mathrm{~cm}$ Csak
5Y 4/2 Olive gray loam. Dry, soft, structureless, friable with no vesicles or roots; strong reaction with acid. Abrupt, smooth boundary with:

5Y 4/1 Dark gray silt. Moist, soft, weak fine platy structure, friable consistency, roots intermittently present, abundant vesicles, a few fine faint $5 Y 4 / 3$ olive mottles. Very strong reaction with acid. Abrupt smooth boundary with:

$5 Y$ 4/1 Dark gray silt. As 3-25 cm but no mottles present. Clear wavy boundary with: 

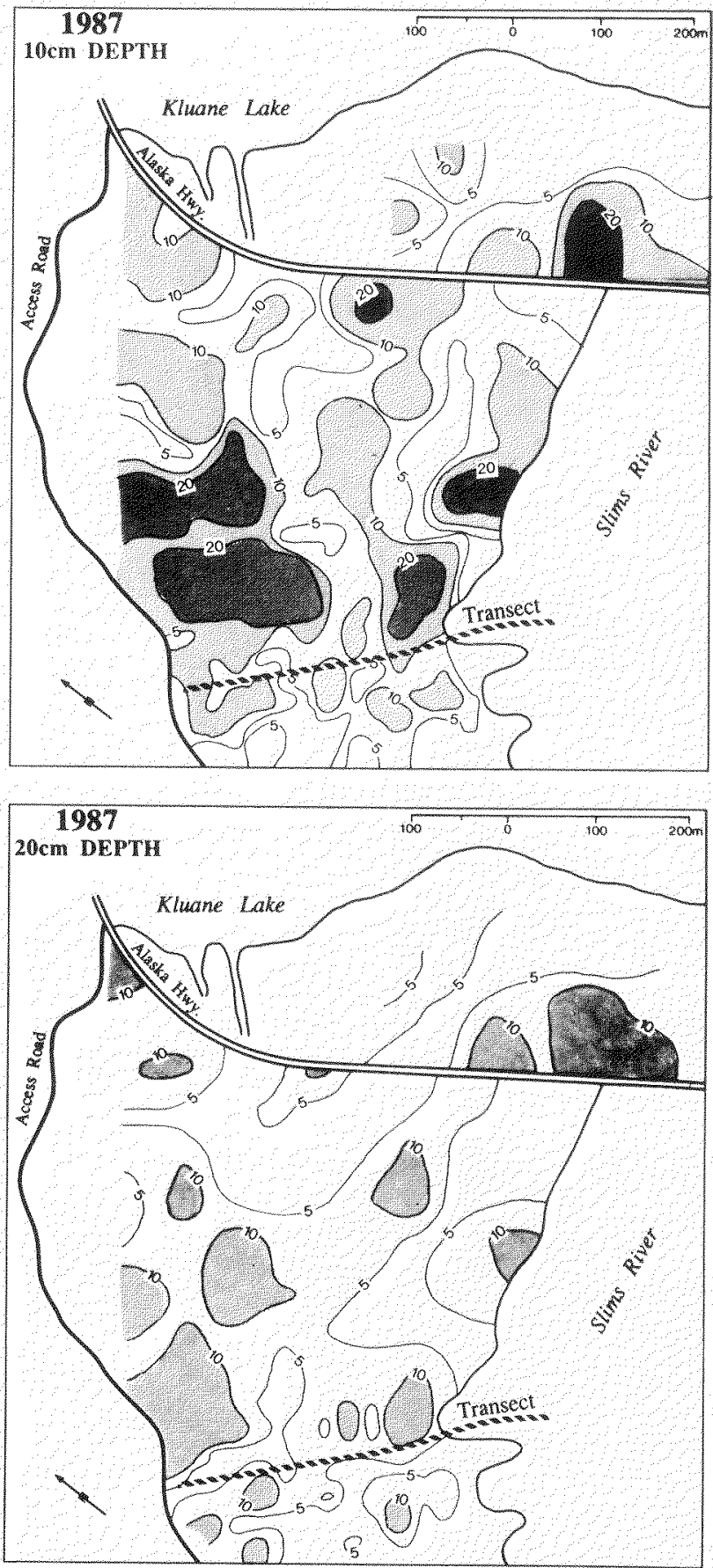

FIG. 10. Distribution of salinity at $10 \mathrm{~cm}$ and $20 \mathrm{~cm}$ along a $100 \mathrm{~m}$ grid on the west side of the Slims River Delta on 12 August 1987. The sampling sites are the same as in Figure 9.

\section{$34 / 36-$} Ck

$44 / 45$

$68 / 69 \mathrm{~cm}$

$\mathrm{Ck}$
5Y 4/1 Dark gray silt. Very moist, soft, weak fine platy structure, friable consistency, fine bedding present, no vesicles or roots present, shimmering mica flakes, a strong reaction with acid. Clear wavy boundary with:

5Y 4/2 Olive gray silty clay loam. Very moist, soft, structureless, friable consistency, saturated bands present, strong reaction with acid, no vesicles, no roots. Clear wavy boundary with:

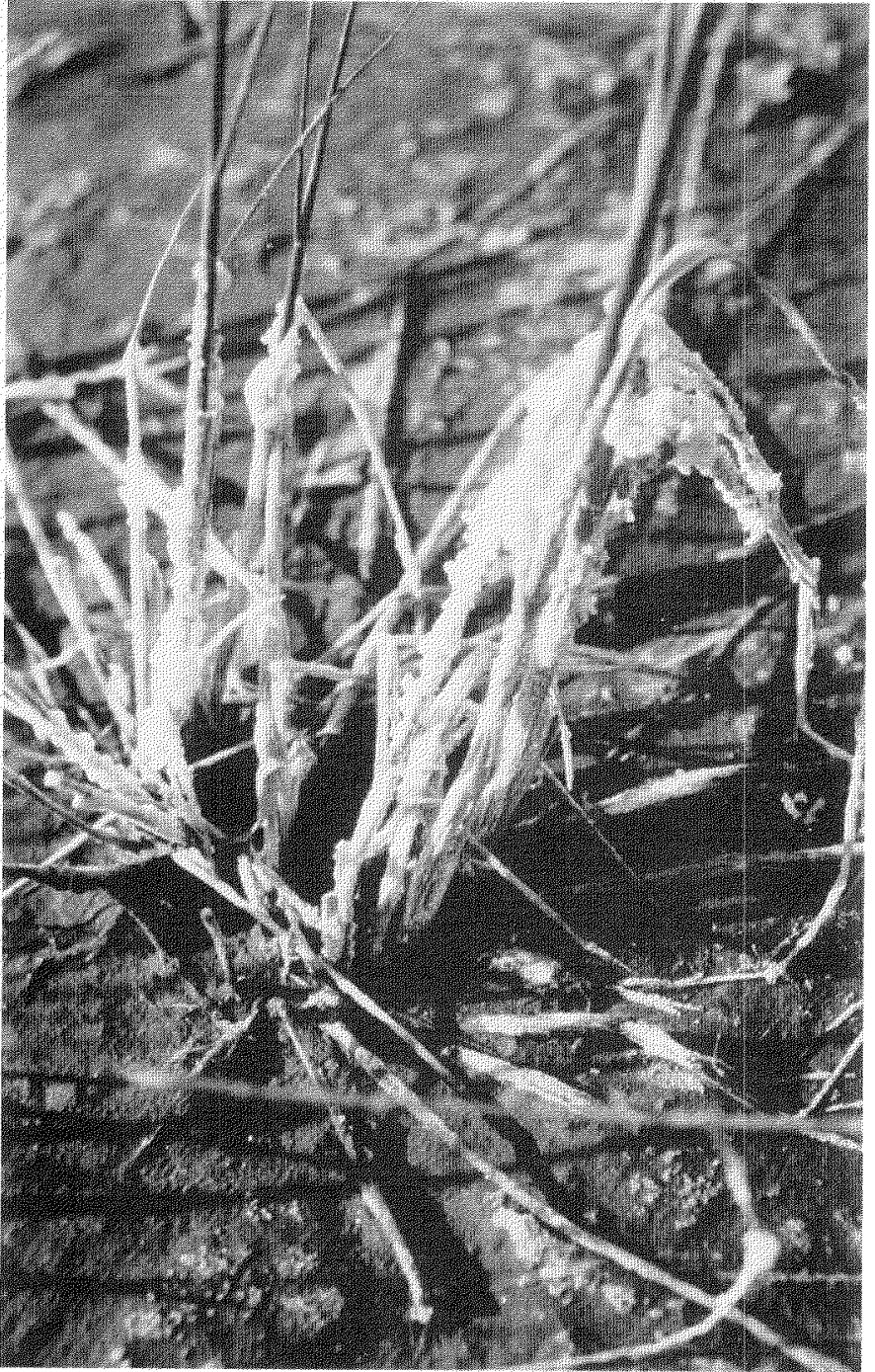

FIG. 11. Typical hydrated magnesium sulfate efflorescence on the stems of vegetation.
68/69$\mathrm{Ck}$
5Y 4/2 Olive gray sand. Very moist, soft, structureless, friable, moderate reaction with acid, few vesicles. Abrupt boundary with frozen sand.
The results of laboratory analysis of the soil samples from Pit TC \#8 are given in Table 9. This is a young soil formed on the overbank deposits adjacent to a distributary channel of the Slims River. Note that salinization is slowly developing and mottling of the surface horizons has just begun. This surface-water gleying must be occurring immediately after snow melt, since this is the only time of the year when the surface horizons are sufficiently wet.

The general, if erratic, decrease in $\mathrm{pH}$ with depth is characteristic of all the profiles on the transect, as is the fine-medium platy structure in the lower horizons of the silty surface material. The platy structure often shows more sandy layers along the horizontal partings, suggesting that the structure may be the result of alluvial deposition of the parent material. Alternatively this structure may develop as the result of freezing and thawing with the development of thin ice lenses (Tedrow, 1977; van Vliet-Lanoë, 1988). 
TABLE 1. Cover, vigour and species composition at the plots of the Aster yukonensis/Deschampsia caespitosa community

\begin{tabular}{|c|c|c|c|c|c|c|c|c|c|c|c|c|c|c|c|c|c|c|c|}
\hline \multirow[b]{2}{*}{ Species } & \multirow[b]{2}{*}{ Factor } & \multicolumn{17}{|c|}{ Plot Number } & \multirow[b]{2}{*}{ Means } \\
\hline & & 11 & 12 & 13 & 10 & 19 & 20 & 21 & 23 & 24 & 25 & 26 & 29 & 30 & 31 & 32 & 33 & 34 & \\
\hline $\begin{array}{l}\text { Aster } \\
\text { yukonensis }\end{array}$ & $\begin{array}{l}\text { Species significance } \\
\% \text { of cover } \\
\text { Vigour }\end{array}$ & $\begin{array}{r}8 \\
65 \\
2\end{array}$ & $\begin{array}{r}7 \\
45 \\
2\end{array}$ & $\begin{array}{r}7 \\
40 \\
2\end{array}$ & $\begin{array}{r}9 \\
90 \\
1\end{array}$ & $\begin{array}{r}8 \\
60 \\
1-2\end{array}$ & $\begin{array}{r}8 \\
70 \\
2\end{array}$ & $\begin{array}{r}7 \\
50 \\
2\end{array}$ & $\begin{array}{r}8 \\
75 \\
2-3\end{array}$ & $\begin{array}{r}8 \\
75 \\
2-3\end{array}$ & $\begin{array}{r}8 \\
75 \\
2-3\end{array}$ & $\begin{array}{r}10 \\
95 \\
1-2\end{array}$ & $\begin{array}{r}8 \\
65 \\
2\end{array}$ & $\begin{array}{r}8 \\
70 \\
2\end{array}$ & $\begin{array}{r}8 \\
65 \\
2\end{array}$ & $\begin{array}{r}8 \\
60 \\
2\end{array}$ & $\begin{array}{r}8 \\
60 \\
2\end{array}$ & $\begin{array}{r}8 \\
60 \\
2\end{array}$ & $\begin{array}{c}8.0 \\
65.9 \\
1.97\end{array}$ \\
\hline $\begin{array}{l}\text { Deschampsia } \\
\text { caespitosa }\end{array}$ & $\begin{array}{l}\text { Species significance } \\
\% \text { of cover } \\
\text { Vigour }\end{array}$ & $\begin{array}{r}6 \\
30 \\
2\end{array}$ & $\begin{array}{r}5 \\
20 \\
2\end{array}$ & $\begin{array}{r}7 \\
40 \\
2\end{array}$ & $\begin{array}{l}- \\
-\end{array}$ & $\begin{array}{r}6 \\
35 \\
2\end{array}$ & $\begin{array}{r}6 \\
25 \\
2\end{array}$ & - & $\begin{array}{r}6 \\
25 \\
2\end{array}$ & $\begin{array}{r}6 \\
25 \\
2\end{array}$ & $\begin{array}{r}6 \\
25 \\
2\end{array}$ & $\begin{array}{l}3 \\
5 \\
1\end{array}$ & $\begin{array}{l}3 \\
5 \\
1\end{array}$ & $\begin{array}{r}6 \\
30 \\
1-2\end{array}$ & $\begin{array}{r}6 \\
30 \\
1-2\end{array}$ & $\begin{array}{r}7 \\
40 \\
1-2\end{array}$ & $\begin{array}{r}7 \\
40 \\
2\end{array}$ & $\begin{array}{r}7 \\
40 \\
2\end{array}$ & $\begin{array}{c}5.1 \\
24.4 \\
1.56\end{array}$ \\
\hline $\begin{array}{l}\text { Ranunculus } \\
\text { cymbalaria }\end{array}$ & $\begin{array}{l}\text { Species significance } \\
\% \text { of cover } \\
\text { Vigour }\end{array}$ & $\begin{array}{l}3 \\
5 \\
1\end{array}$ & $\begin{array}{r}5 \\
20 \\
1\end{array}$ & $\begin{array}{r}5 \\
20 \\
1\end{array}$ & - & - & $\begin{array}{l}- \\
-\end{array}$ & $\begin{array}{l}- \\
-\end{array}$ & $\begin{array}{l}- \\
- \\
-\end{array}$ & $\begin{array}{l}- \\
-\end{array}$ & $\begin{array}{l}- \\
- \\
-\end{array}$ & $\begin{array}{l}- \\
- \\
-\end{array}$ & $\begin{array}{l}- \\
-\end{array}$ & - & $\begin{array}{l}- \\
-\end{array}$ & $\begin{array}{l}- \\
-\end{array}$ & $\begin{array}{l}- \\
-\end{array}$ & $\begin{array}{l}- \\
-\end{array}$ & $\begin{array}{l}0.8 \\
2.6 \\
0.18\end{array}$ \\
\hline $\begin{array}{l}\text { Juncus } \\
\text { arcticus }\end{array}$ & $\begin{array}{l}\text { Species significance } \\
\% \text { of cover } \\
\text { Vigour }\end{array}$ & $\begin{array}{l}- \\
-\end{array}$ & $\begin{array}{r}3 \\
\leq 5 \\
1-2\end{array}$ & $\begin{array}{l}- \\
- \\
-\end{array}$ & - & - & $\frac{-}{-}$ & - & $\begin{array}{l}- \\
-\end{array}$ & $\begin{array}{l}- \\
-\end{array}$ & $\frac{-}{-}$ & $\begin{array}{l}- \\
- \\
-\end{array}$ & $\begin{array}{l}- \\
-\end{array}$ & $\begin{array}{l}- \\
- \\
-\end{array}$ & $\begin{array}{r}3 \\
5 \\
2-3\end{array}$ & $\begin{array}{l}- \\
-\end{array}$ & $\overline{-}$ & $\begin{array}{l}- \\
-\end{array}$ & $\begin{array}{l}0.4 \\
0.6 \\
0.24\end{array}$ \\
\hline $\begin{array}{l}\text { Triglochin } \\
\text { palustris }\end{array}$ & $\begin{array}{l}\text { Species significance } \\
\% \text { of cover } \\
\text { Vigour }\end{array}$ & - & $\begin{array}{r}3 \\
\leq 5 \\
1\end{array}$ & $\begin{array}{l}- \\
- \\
-\end{array}$ & $\begin{array}{l}- \\
- \\
-\end{array}$ & - & $\begin{array}{l}- \\
-\end{array}$ & - & $\begin{array}{l}- \\
- \\
-\end{array}$ & $\begin{array}{l}- \\
- \\
-\end{array}$ & $\begin{array}{l}- \\
-\end{array}$ & $\begin{array}{l}- \\
-\end{array}$ & $\underline{-}$ & $\begin{array}{l}- \\
-\end{array}$ & - & $\underline{-}$ & - & $\begin{array}{l}- \\
- \\
-\end{array}$ & $\begin{array}{l}0.2 \\
0.3 \\
0.06\end{array}$ \\
\hline $\begin{array}{l}\text { Hordeum } \\
\text { jubatum }\end{array}$ & $\begin{array}{l}\text { Species significance } \\
\% \text { of cover } \\
\text { Vigour }\end{array}$ & $\begin{array}{l}- \\
-\end{array}$ & $\begin{array}{r}3 \\
\leq 5 \\
1\end{array}$ & $\begin{array}{l}- \\
-\end{array}$ & - & $\begin{array}{r}2-3 \\
\leq 5 \\
3\end{array}$ & $\begin{array}{l}3 \\
5 \\
1\end{array}$ & $\begin{array}{r}4 \\
10 \\
1\end{array}$ & $\begin{array}{l}- \\
-\end{array}$ & $\begin{array}{l}- \\
-\end{array}$ & $\begin{array}{l}- \\
-\end{array}$ & $\begin{array}{l}- \\
-\end{array}$ & $\overline{-}$ & $\overline{-}$ & - & $\overline{-}$ & $\begin{array}{l}- \\
-\end{array}$ & $\begin{array}{l}- \\
-\end{array}$ & $\begin{array}{l}0.8 \\
1.5 \\
0.35\end{array}$ \\
\hline $\begin{array}{l}\text { Puccinellia } \\
\text { nuttalliana }\end{array}$ & $\begin{array}{l}\text { Species significance } \\
\% \text { of cover } \\
\text { Vigour }\end{array}$ & $\begin{array}{l}- \\
- \\
-\end{array}$ & - & $\begin{array}{l}- \\
- \\
-\end{array}$ & $\begin{array}{r}4 \\
10 \\
1\end{array}$ & $\begin{array}{l}- \\
- \\
-\end{array}$ & - & $\begin{array}{r}7 \\
40 \\
1-2\end{array}$ & $\begin{array}{l}- \\
-\end{array}$ & $\begin{array}{l}- \\
-\end{array}$ & $\begin{array}{l}- \\
-\end{array}$ & $\begin{array}{l}- \\
- \\
-\end{array}$ & $\overline{-}$ & $\begin{array}{l}- \\
-\end{array}$ & $\begin{array}{l}- \\
- \\
-\end{array}$ & $\begin{array}{l}- \\
-\end{array}$ & $\begin{array}{l}- \\
- \\
-\end{array}$ & $\begin{array}{l}- \\
- \\
-\end{array}$ & $\begin{array}{l}0.6 \\
2.9 \\
0.15\end{array}$ \\
\hline Total cover $\%$ & & 10 & 15 & 15 & 10 & 20 & $20-25$ & 15 & 20 & $20-25$ & $20-2$ & $20-25$ & $20-25$ & $20-25$ & $15-20$ & $15-20$ & $15-20$ & $15-20$ & 18.2 \\
\hline
\end{tabular}

\begin{tabular}{lllllr}
\hline \hline Vigour scale & \multicolumn{4}{l}{ Species significance scale - cover range for each value } \\
0 & Dead & Seldom, cover negligible & 1 & Very often, cover 20-35\% of plot & 6 \\
1 & Poor & Very scattered, cover negligible & 2 & Abundant, cover 35-50\% of plot & 7 \\
2 & Average & Scattered, cover up to 5\% of plot & 3 & Abundant, cover 50-75\% of plot & 8 \\
3 & Excellent & Common, cover 5-10\% of plot & 4 & Abundant, cover 75-95\% of plot & 9 \\
& & Often, cover 10-20\% of plot & 5 & Abundant, cover 95-100\% of plot & 10
\end{tabular}

An example of a well-developed profile of solonchak-type is as follows:

\section{Pit TC \#7}

Crest of very slight rise on Slims River floodplain deposits, Slims River Delta, Kluane National Park, Yukon Territory There are a few scattered plants of Deschampsia caespitosa $(<5 \%$ cover). The ground surface shows a typical white powdery salt efflorescence (Fig. 12) of a classic solonchak.

$0-3 / 5 \mathrm{~cm}$

Csak

$3 / 5-10 \mathrm{~cm}$ Csakg

$10-31 \mathrm{~cm}$ Csakg

$31-43 \mathrm{~cm}$ Csak
5 YR4/2Olivegray silt loam. Dry, soft, welldeveloped fine crumb structure, very friable consistency, roots present, moderate reaction with acid, no mottles. Clear, wavy boundary with:

5YR 4/2 Olive gray silt. Moist, soft, moderate fine platy structure, friable consistency, roots present, also a few medium, distinct to prominent 2.5 Y $5 / 3$ grayish brown mottles, strong reaction with acid. Clear, smooth boundary with:

5YR 4/2 Olive gray silt. Moist, soft, weak fine platy structure, friable consistency, roots common to $19 \mathrm{~cm}$, more below, abundant vesicles, distinct to prominent $2.5 \mathrm{Y} 5 / 3$ grayish brown mottles, strong reaction with acid. Abrupt, smooth boundary with:

5YR 4/2Olive gray silt load-silt. Moist, soft, structureless apart form weak fine stratifi-

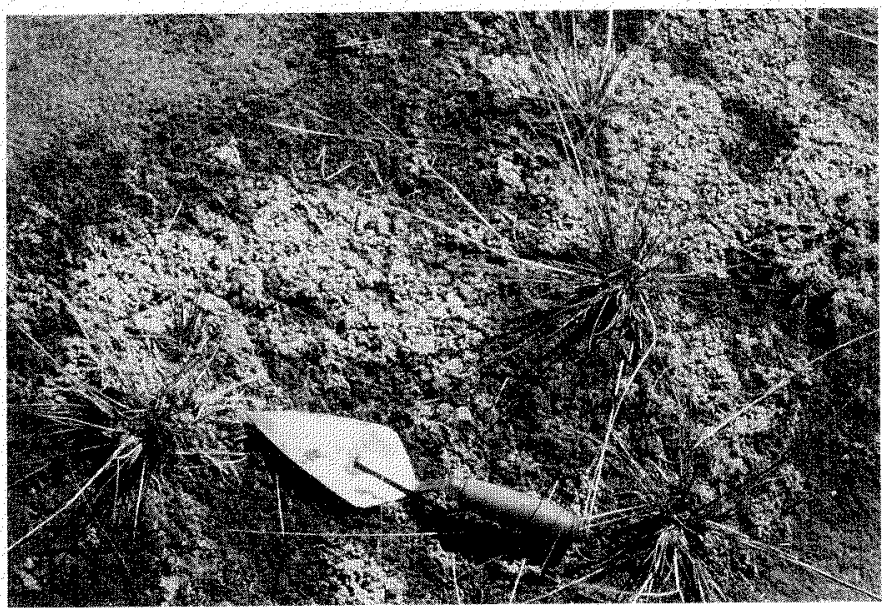

FIG. 12. Surface structure of solonchak soils on ridges.

cation, friable consistency, shimmering mica flakes, no roots or mottles, moderate reaction with acid. Abrupt wavy boundary with:

43-63 cm 5YR 4/2Olive gray silt. Moist, soft, moderCsak ate fine to medium platy structure, friable consistency, strong reaction with acid, no roots or mottles. Clear wavy boundary with:

63-90 cm max. 5 YR 4/2 Olive gray sand loam. Moist, soft, Csak structureless, friable consistency, moderate reaction with acid, no roots or mottles. 
TABLE 2. Cover, vigour and species composition at the plots of the Deschampsis caespitosa/Aster yukonensis community (for scales, see Table 1)

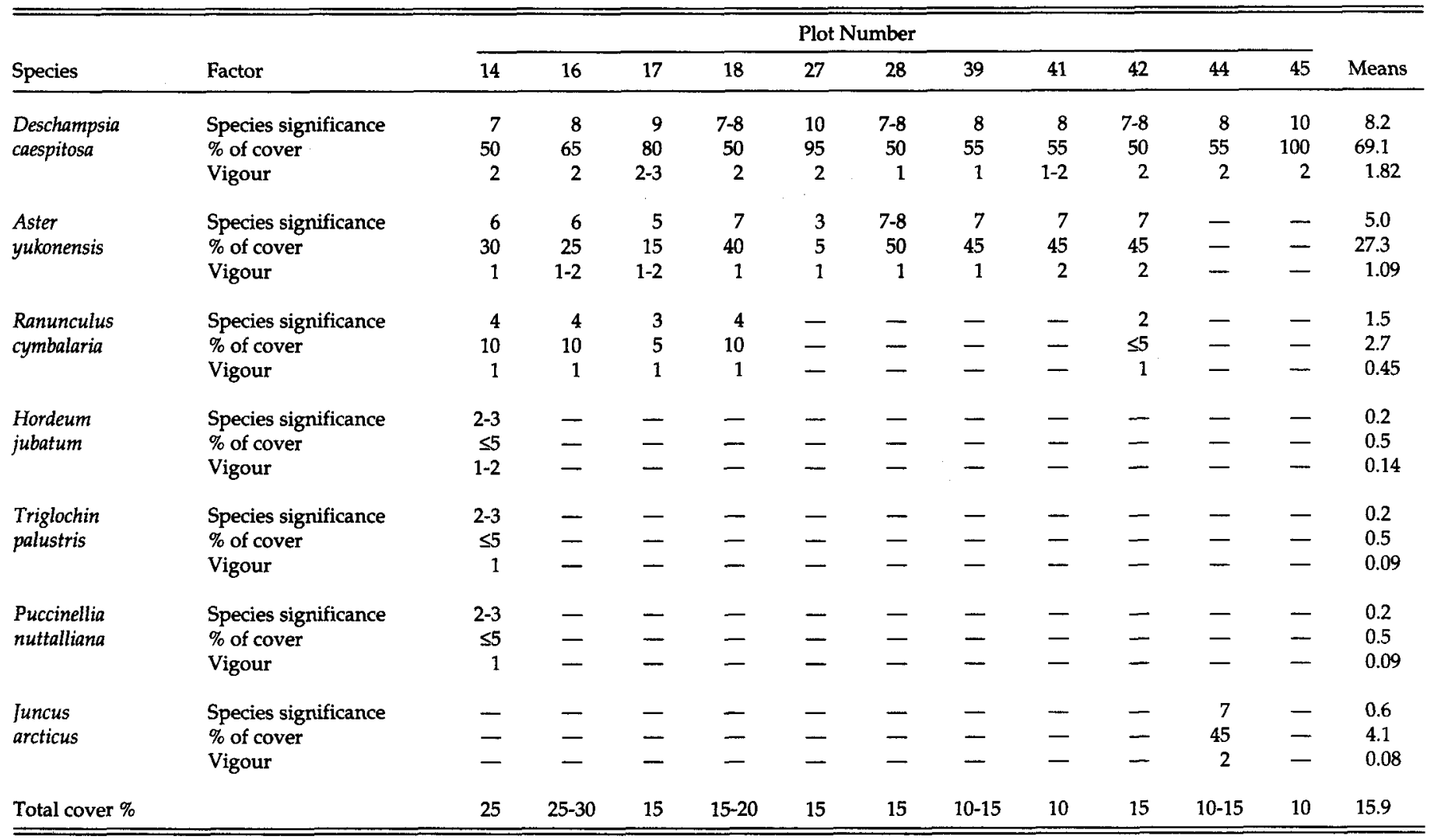

TABLE 3. Cover, vigour and species composition of the plots of the Triglochin palustris/Puccinellia nuttalliana community (for scales, see Table 1)

\begin{tabular}{|c|c|c|c|c|c|c|c|c|}
\hline \multirow[b]{2}{*}{ Species } & \multirow[b]{2}{*}{ Factor } & \multicolumn{6}{|c|}{ Plot Number } & \multirow[b]{2}{*}{ Mean } \\
\hline & & 1 & 2 & 3 & 4 & 5 & 6 & \\
\hline $\begin{array}{l}\text { Triglochin } \\
\text { palustris }\end{array}$ & $\begin{array}{l}\text { Species significance } \\
\% \text { of cover } \\
\text { Vigour }\end{array}$ & $\begin{array}{r}6 \\
35 \\
3\end{array}$ & $\begin{array}{r}10 \\
90 \\
3\end{array}$ & $\begin{array}{r}6 \\
35 \\
3\end{array}$ & $\begin{array}{r}6 \\
25 \\
3\end{array}$ & $\overline{-}$ & $\begin{array}{r}6 \\
25 \\
1\end{array}$ & $\begin{array}{c}5.7 \\
35.0 \\
2.17\end{array}$ \\
\hline $\begin{array}{l}\text { Puccinellia } \\
\text { nuttalliana }\end{array}$ & $\begin{array}{l}\text { Species significance } \\
\% \text { of cover } \\
\text { Vigour }\end{array}$ & $\begin{array}{r}6 \\
25 \\
2\end{array}$ & $\overline{-}$ & $\begin{array}{r}8 \\
60 \\
2\end{array}$ & $\begin{array}{r}8 \\
70 \\
3\end{array}$ & $\begin{array}{r}6 \\
35 \\
1-2\end{array}$ & $\begin{array}{r}6 \\
25 \\
1\end{array}$ & $\begin{array}{c}5.7 \\
35.8 \\
1.58\end{array}$ \\
\hline $\begin{array}{l}\text { Aster } \\
\text { yukonensis }\end{array}$ & $\begin{array}{l}\text { Species significance } \\
\% \text { of cover } \\
\text { Vigour }\end{array}$ & $\begin{array}{r}6 \\
30 \\
3\end{array}$ & $\bar{z}$ & $\begin{array}{l}- \\
-\end{array}$ & - & $\begin{array}{r}6 \\
35 \\
2\end{array}$ & $\begin{array}{r}7 \\
40 \\
1\end{array}$ & $\begin{array}{r}3.2 \\
17.50 \\
1.00\end{array}$ \\
\hline $\begin{array}{l}\text { Hordeum } \\
\text { jabatum }\end{array}$ & $\begin{array}{l}\text { Species significance } \\
\% \text { of cover } \\
\text { Vigour }\end{array}$ & $\begin{array}{r}4 \\
10 \\
2\end{array}$ & - & $\begin{array}{l}3 \\
5 \\
2\end{array}$ & $\begin{array}{l}3 \\
5 \\
2\end{array}$ & $\begin{array}{l}3 \\
5 \\
2\end{array}$ & $\overline{-}$ & $\begin{array}{l}2.17 \\
4.2 \\
1.33\end{array}$ \\
\hline $\begin{array}{l}\text { Juncus } \\
\text { arcticus }\end{array}$ & $\begin{array}{l}\text { Species significance } \\
\% \text { of cover } \\
\text { Vigour }\end{array}$ & $\frac{-}{-}$ & $\begin{array}{r}4 \\
10 \\
3\end{array}$ & $\begin{array}{l}- \\
-\end{array}$ & $\overline{-}$ & - & $\overline{-}$ & $\begin{array}{l}0.7 \\
1.7 \\
0.50\end{array}$ \\
\hline $\begin{array}{l}\text { Ranunculus } \\
\text { cymbalaria }\end{array}$ & $\begin{array}{l}\text { Species significance } \\
\% \text { of cover } \\
\text { Vigour }\end{array}$ & $\frac{-}{-}$ & $\overline{-}$ & $\overline{-}$ & $\begin{array}{l}- \\
-\end{array}$ & $\begin{array}{r}6 \\
25 \\
2\end{array}$ & $\begin{array}{l}3 \\
5 \\
3\end{array}$ & $\begin{array}{l}1.5 \\
5.0 \\
0.83\end{array}$ \\
\hline \multicolumn{2}{|c|}{ Total cover $(\%)$} & $10-15$ & 10 & 15 & 25 & $15-20$ & 10 & 15.00 \\
\hline
\end{tabular}

Table 10 shows the results of laboratory analysis of soil samples from the Pit TC \#7 profile. This is fairly typical of the well-developed solonchak soils of Asia. At the surface is a layer with a well-developed fine crumb structure, overlying horizons with a fine platy structure and containing abundant small vesicles.

An example of the weak solonetz profile is as follows:

\section{Pit TC \#3}

Soil developed at a lower site on the Slims River Delta, Kluane National Park, Yukon Territory - The surface shows marked polygonal cracking with salt accumulations along the margins of the cracks. Deschampsia caespitosa and Aster yukonensis occur on the surface, forming a $10 \%$ cover. Frozen ground at $174 \mathrm{~cm}$.

$$
\begin{aligned}
& 0-9 / 15 \mathrm{~cm} \\
& \text { Csakgj } \\
& 9 / 15-20 \mathrm{~cm} \\
& \text { Csakgj }
\end{aligned}
$$

5Y 4/1 dark gray silt loam. Just moist, fairly soft, moderately well-developed fine subangular blocky, with very coarse prismatic structure, friable consistency, abundant vesicles, white streaks of salts, a few fine, faint $5 Y 4 / 4$ olive mottles present, strong reaction to acid, roots present. Gradual irregular boundary with:

$5 Y 4.5 / 1$ Dark gray silt. As $0-9 / 15 \mathrm{~cm}$ but weak fine platy and coarse prismatic structure and no white streaks of salts. Clear wavy boundary with: 
TABLE 4. Cover, vigor and species composition of the plots of the Puccinellia nuttalliana community (for scales, see Table 1)

\begin{tabular}{|c|c|c|c|c|c|c|c|c|}
\hline \multirow[b]{2}{*}{ Species } & \multirow[b]{2}{*}{ Factor } & \multicolumn{6}{|c|}{ Plot Number } & \multirow[b]{2}{*}{ Mean } \\
\hline & & 1 & 2 & 3 & 4 & 5 & 6 & \\
\hline \multirow{3}{*}{$\begin{array}{l}\text { Puccinellia } \\
\text { nuttalliana }\end{array}$} & Species significance & 7 & 6 & 10 & 10 & 10 & 7.8 & 8.4 \\
\hline & $\%$ of cover & 45 & 35 & 100 & 100 & 100 & 50 & 71.7 \\
\hline & Vigour & $1-2$ & $1-2$ & 1 & 1 & 1 & $1-2$ & 1.25 \\
\hline \multirow{3}{*}{$\begin{array}{l}\text { Aster } \\
\text { yukonensis }\end{array}$} & Species significance & 7 & 6 & 一 & 一 & - & 7 & 3.3 \\
\hline & $\%$ of cover & 40 & 25 & - & - & - & 45 & 1.8 \\
\hline & Vigour & $1-2$ & 2 & - & - & - & 1 & 0.75 \\
\hline \multirow{3}{*}{$\begin{array}{l}\text { Ranunculus } \\
\text { cymbalaria }\end{array}$} & Species significance & 4 & - & - & - & - & - & 0.7 \\
\hline & $\%$ of cover & 10 & - & - & - & - & - & 1.6 \\
\hline & Vigour & 2 & - & - & - & - & - & 0.33 \\
\hline \multirow{3}{*}{$\begin{array}{l}\text { Hordeum } \\
\text { jabatum }\end{array}$} & Species significance & 3 & 5 & - & - & - & 3 & 1.8 \\
\hline & $\%$ of cover & 5 & 15 & - & - & - & 5 & 4.2 \\
\hline & Vigour & $1-2$ & 1 & - & - & - & 1 & 0.58 \\
\hline \multirow{3}{*}{$\begin{array}{l}\text { Deschampsia } \\
\text { caespitosa }\end{array}$} & Species significance & - & 6 & - & - & - & - & 1.0 \\
\hline & $\%$ of cover & - & 25 & - & - & - & - & 4.2 \\
\hline & Vigour & - & 2 & - & - & - & - & 0.33 \\
\hline \multicolumn{2}{|c|}{ Total cover $(\%)$} & 10 & 20 & $15-20$ & 15 & 15 & 25 & 17.1 \\
\hline
\end{tabular}

TABLE 5. Cover, vigour and species composition of the plots of the Juncus arcticus/Deschampsia caespitosa community (for scales, see Table 1)

\begin{tabular}{|c|c|c|c|c|c|}
\hline \multirow[b]{2}{*}{ Species } & \multirow[b]{2}{*}{ Factor } & \multicolumn{3}{|c|}{ Plot Number } & \multirow[b]{2}{*}{ Mean } \\
\hline & & 15 & 40 & 43 & \\
\hline \multirow{3}{*}{$\begin{array}{l}\text { Juncus } \\
\text { arcticus }\end{array}$} & Species significance & 6 & 9 & 8 & 7.7 \\
\hline & $\%$ of cover & 25 & 80 & 65 & 56.7 \\
\hline & Vigour & 2 & $2-3$ & 2 & 2.17 \\
\hline \multirow{3}{*}{$\begin{array}{l}\text { Deschampsia } \\
\text { caespitosa }\end{array}$} & Species significance & 5 & 5 & 6 & 5.3 \\
\hline & $\%$ of cover & 15 & 20 & 35 & 23.3 \\
\hline & Vigour & 2 & 2 & $1-2$ & 1.83 \\
\hline \multirow{3}{*}{$\begin{array}{l}\text { Salix } \\
\text { brachycarpa ssp. } \\
\text { niphoclada }\end{array}$} & Species significance & 7 & - & - & 2.3 \\
\hline & $\%$ of cover & 40 & - & - & 13.3 \\
\hline & Vigour & 1 & - & - & 0.33 \\
\hline \multirow{3}{*}{$\begin{array}{l}\text { Plantago } \\
\text { maritima }\end{array}$} & Species significance & 2 & - & - & 0.7 \\
\hline & $\%$ of cover & 5 & - & - & 1.7 \\
\hline & Vigour & 1 & - & - & 0.33 \\
\hline \multirow{3}{*}{$\begin{array}{l}\text { Ranunculus } \\
\text { cymbalaria }\end{array}$} & Species significance & 2 & - & - & 0.7 \\
\hline & $\%$ of cover & 5 & - & - & 1.7 \\
\hline & Vigour & 1 & - & - & 0.33 \\
\hline \multirow{3}{*}{$\begin{array}{l}\text { Hordeum } \\
\text { jabatum }\end{array}$} & Species significance & 2 & - & - & 0.7 \\
\hline & $\%$ of cover & 5 & - & - & 1.7 \\
\hline & Vigour & 1 & - & - & 0.33 \\
\hline \multicolumn{2}{|l|}{ Total cover (\%) } & 40 & 15 & 15 & 23.3 \\
\hline
\end{tabular}

$20-26 / 29 \mathrm{~cm}$ Csak

$26 / 29-45 \mathrm{~cm}$ Csak
5Y 4.5/1 Dark gray silt. Moist, soft, weak fine platy and coarse prismatic structure, friable consistency, roots present, no mottles or white streaks of salts, strong reaction to acid. Clear wavy boundary with:

5Y 4/2 Olive gray silt loam. Moist, soft, moderate to strong fine platy structure, no prismatic cracking, friable consistency, no roots present, strong reaction with acid. Clean smooth boundary with:
TABLE 6. Cover, vigour and species composition of the plots of the Ranunculus cymbalaria community (for scales, see Table 1)

\begin{tabular}{|c|c|c|c|c|c|c|}
\hline \multirow[b]{2}{*}{ Species } & \multirow[b]{2}{*}{ Factor } & \multicolumn{4}{|c|}{ Plot Number } & \multirow[b]{2}{*}{ Mean } \\
\hline & & $6 \mathrm{~A}$ & $6 \mathrm{~B}$ & 7 & 8 & \\
\hline \multirow{3}{*}{$\begin{array}{l}\text { Ranunculus } \\
\text { cymbalaria }\end{array}$} & Species significance & 10 & 10 & 10 & 10 & 10.0 \\
\hline & $\%$ of cover & 100 & 95 & $90-95$ & 95 & 95.6 \\
\hline & Vigour & $1-2$ & 1 & 2 & 2 & 1.63 \\
\hline \multirow{3}{*}{$\begin{array}{l}\text { Plantago } \\
\text { maritima }\end{array}$} & Species significance & - & 2 & 2 & - & 1.0 \\
\hline & $\%$ of cover & - & 5 & 5 & - & 2.5 \\
\hline & Vigour & - & 2 & 2 & - & 1.00 \\
\hline \multirow{3}{*}{$\begin{array}{l}\text { Aster } \\
\text { yukonensis }\end{array}$} & Species significance & - & - & 2 & - & 0.5 \\
\hline & $\%$ of cover & - & - & 5 & - & 1.3 \\
\hline & Vigour & - & - & 1 & - & 0.25 \\
\hline \multirow{3}{*}{$\begin{array}{l}\text { Puccinellia } \\
\text { nuttalliana }\end{array}$} & Species significance & - & - & 2 & 2 & 1.0 \\
\hline & $\%$ of cover & - & - & 5 & 5 & 2.5 \\
\hline & Vigour & - & - & 1 & 1 & 0.50 \\
\hline \multicolumn{2}{|c|}{ Total cover (\%) } & 10 & 10 & 10 & 10 & 10.0 \\
\hline
\end{tabular}

TABLE 7. Soil moisture and electrical conductivity range for each plant community based on 1985 data compared with the electrical conductivity range for $1985-87$

\begin{tabular}{lccc}
\hline & $\begin{array}{c}\text { 1985 soil } \\
\text { moisture } \\
\text { (\% by weight) }\end{array}$ & $\begin{array}{c}1985 \text { electrical } \\
\text { conductivity } \\
\text { (mS/cm) }\end{array}$ & $\begin{array}{c}1985-87 \\
\text { electrical } \\
\text { conductivity } \\
\text { (mS/cm) }\end{array}$ \\
\hline $\begin{array}{l}\text { Triglochin palustris/ } \\
\text { Puccinellia nuttalliana }\end{array}$ & $29-35$ & $4.00-4.97$ & $2.00-18.50$ \\
$\begin{array}{l}\text { Juncus arcticus/ } \\
\text { Deschampsia caespitosa }\end{array}$ & $27-30$ & $1.60-2.87$ & $0.10-12.50$ \\
$\begin{array}{l}\text { Populus balsamifera } \\
\text { Aster yukonensis/ }\end{array}$ & $25-27$ & $0.02-2.75$ & $0.00-15.20$ \\
Deschampsia caespitosa & $24-28$ & $1.19-4.48$ & $0.10-15.50$ \\
$\begin{array}{l}\text { Deschampsia caespitosa/ } \\
\text { Aster yukonensis }\end{array}$ & $24-28$ & $1.03-4.07$ & $0.10-15.50$ \\
$\begin{array}{l}\text { Puccinellia nuttalliana } \\
\text { Ranunculus cymbalaria }\end{array}$ & $13-20$ & $4.08-4.97$ & $2.00-45.00$ \\
\begin{tabular}{l} 
Barren area \\
\hline \hline
\end{tabular} & $10-14$ & $4.08-4.07$ & $0.10-18.00$ \\
\hline
\end{tabular}

$45-61 \mathrm{~cm}$
Csak

$5 Y 5 / 2$ Olive gray silt loam. Moist, soft, weak to moderate fine platy structure, friable consistency, no roots present, strong reaction with acid. Gradual wavy boundary with:

61-174 cm max. 5Y 5/2 Olive gray sandy loam. Moist, soft, Csak structureless, friable consistency, moderate reaction with acid. No roots present.

Table 11 shows the results of laboratory analysis of soil samples from Pit TC \#3. This type of profile is found on the lower parts of the delta surface and can be readily recognized by the marked coarse polygonal cracking of the soil surface (Fig. 13). The tops of the prisms tend to show a smooth, relatively impervious crust, and the limited vegetation usually grows along the sides of the cracks, probably due to more 
TABLE 8. Salinity tolerances of the species found growing on soils with a salinity greater than $4 \mathrm{mS} / \mathrm{cm}$ on the Slims River Delta

SPECIES
Puccinella nuttalliana
Hordeum jubatum
Aster pygmaeus
Carex manitima
Salix alaxensis ssp. alaxensis
Triglochin palustris
Aster yukonensis
Ranunaulus cymbalaria
Deschampsia caespitosa
Populus balsamifera ssp. balsamifera
Plantago maritima ssp. juncoides
Salix brachycarpa ssp. niphoclada
Juncus articus ssp. arcticus
Carex parni
Juncus balticus var. littoralis
Eurotia lanata

\section{CONDUCTIVITY ( $\mathrm{m} \mathrm{S} / \mathrm{cm})$}

\section{$0-4 \mathrm{mS} / \mathrm{cm}$}

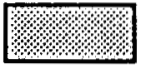

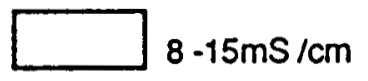

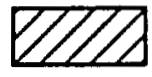

$15 \mathrm{mS} / \mathrm{cm}$ leaching and better drainage and aeration. The cracks may be up to $50 \mathrm{~cm}$ deep, and the prisms have an angular to subangular blocky structure, indicating higher density.

The lower electrical conductivity is obvious in the analyses, but the horizons remain somewhat friable, probably due to the high sulfate content. Thus these soils have the external structure found where chlorides are the dominant salts. These soils continue to the edges of small residual ponds in depressions without any greater leaching or the development of solods.

\section{DISCUSSION}

\section{Origin of the Salts}

Salinization is one of the major soil-forming processes that must be taken into account in agriculture and in the study of soils. North America is fortunate that it has few areas of true desert (see White, 1960:Fig. 1), so that under natural conditions, saline soils are relatively rare and occupy small areas of the landscape (Soil Survey Staff, 1975:177). On other continents, saline silts are found throughout substantial areas, particularly in Eastern Europe, North Africa and Asia. The classic work of Kovda indicated that groundwater is commonly the source of the salts and that there is a definite sequence of stages in the salt accumulation from weathering of silicate and carbonate minerals, which are characterized by the changes in cations and anions present in the groundwater and soil (Kovda, 1947). In more humid areas, sodium carbonate is dominant, which grades via sulfate-dominated soils and groundwaters to sodium chloride-dominated groundwaters in the low-lying desert areas around the lower reaches of the river systems east of the Caspian Sea. These have been

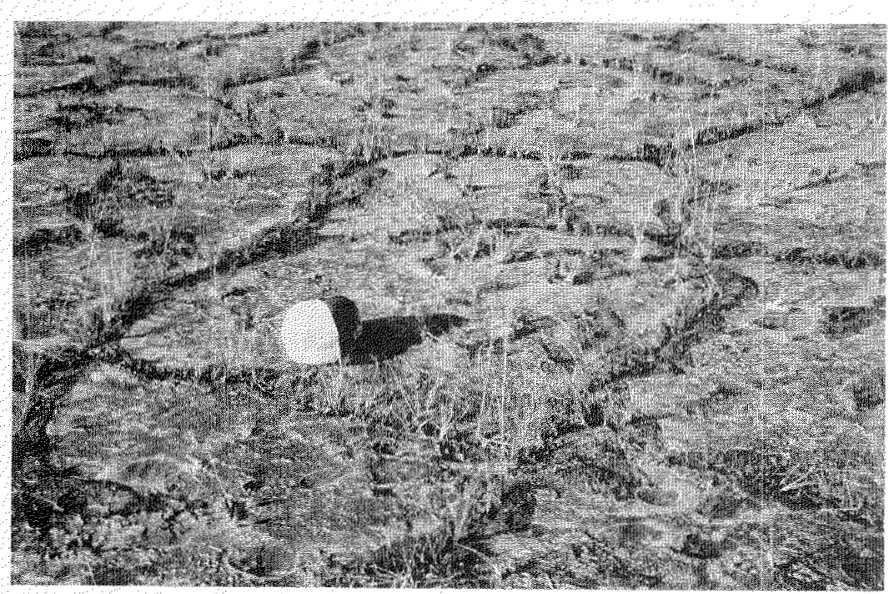

FIG. 13. Polygonal cracking in solonetzic soils in depressions. Note the way the vegetation tends to grow along the margins of the polygonal cracks. 
TABLE 9. Chemical analyses of lake, river, spring and groundwater from the Slims River Delta

\begin{tabular}{|c|c|c|c|c|c|c|}
\hline & $\begin{array}{l}\text { Kluane } \\
\text { Lake }^{\text {a }}\end{array}$ & $\begin{array}{l}\text { Slims River } \\
\text { Alaska Hwy. }\end{array}$ & $\begin{array}{l}\text { Spring E. } \\
\text { of bridge }^{a}\end{array}$ & $\begin{array}{l}\text { Spring W. } \\
\text { of bridge }^{\mathrm{a}}\end{array}$ & $\begin{array}{c}\text { Pond in } \\
\text { saline area }\end{array}$ & $\begin{array}{l}\text { Ground } \\
\text { water on } \\
\text { transect }\end{array}$ \\
\hline Conductivity (mS/cm) & $0.27-0.31$ & $0.18-0.425$ & $0.60-0.73$ & $1.66-3.63$ & $25.0-48.5$ & n.d. \\
\hline TDS (ppm) & $196-338$ & $418-1362$ & $552-586$ & $1635-8569$ & n.d. & n.d. \\
\hline $\mathrm{pH}$ & $7.40-8.30$ & $7.80-8.30$ & $8.10-8.30$ & $7.90-8.30$ & 8.4 & n.d. \\
\hline $\begin{array}{c}\text { Ions }(\mathrm{meg} / \mathrm{L}) \\
\mathrm{Ca}^{++}\end{array}$ & $1.99-2.08$ & $3.08-3.0$ & $4.66-4.71$ & $7.75-24.1$ & $17.75-2.3$ & 191.0 \\
\hline $\mathrm{Mg}^{++}$ & $0.75-0.90$ & $1.18-1.25$ & $2.46-2.71$ & $13.50-77.2$ & 30.67 & 287.0 \\
\hline $\mathrm{K}^{+}$ & $0.13-0.15$ & $0.20-0.24$ & $0.19-0.22$ & $0.80-5.22$ & n.d. & 35.6 \\
\hline $\mathrm{Na}^{+}$ & $0.14-0.15$ & 0.16 & $0.21-0.23$ & $0.98-8.61$ & $109.56-132.17$ & 141.0 \\
\hline $\mathrm{Cl}^{-}$ & 0.02 & 0.02 & 0.03 & $0.52-0.31$ & $29.58-95.77$ & n.d. \\
\hline $\mathrm{SO}_{4} \cdot \cdots$ & $1.73-1.92$ & $2.70-3.0$ & $4.20-5.20$ & $24.95-1225$ & 2500 & n.d. \\
\hline $\mathrm{NO}_{\jmath}^{-}$ & $\operatorname{Tr}$. & Tr. & Tr. & $\operatorname{Tr}$ & n.d. & n.d. \\
\hline Numbers of samples & 3 & 3 & 3 & 2 & 2 & 1 \\
\hline Site \# (Fig. 1) & 1 & 2 & 3 & 4 & 5 & 6 \\
\hline
\end{tabular}

${ }^{a}$ Analyses by Groundwater Laboratory, Environment Canada, Vancouver. Courtesy of Gerry Whitley.

${ }^{b}$ Analyses by atomic absorption spectroscopy by D.R. Levinson, Department of Geology, University of Calgary.

TABLE 10. Results of laboratory analysis of soil samples from Pit TC \#8, Slims River Delta

\begin{tabular}{|c|c|c|c|c|c|c|c|c|}
\hline \multirow[b]{2}{*}{ Depth (cm) } & \multicolumn{3}{|c|}{ Particle size (\%) } & \multirow[b]{2}{*}{ Texture } & \multirow[b]{2}{*}{$\mathrm{pH}$} & \multicolumn{3}{|c|}{$\begin{array}{l}\text { Electrical conductivity } \\
(\mathrm{mS} / \mathrm{cm})\end{array}$} \\
\hline & Sand & Silt & Clay & & & $29 / 6 / 85$ & $31 / 5 / 86$ & $6 / 8 / 87$ \\
\hline $0-3$ & 49 & 46 & 5 & $\mathrm{~L}$ & 8.35 & 3.00 & 12.0 & 10.5 \\
\hline $3-34 / 36$ & 6 & 83 & 11 & $\mathrm{Si}$ & 7.68 & 1.25 & 8.7 & 5.0 \\
\hline $34 / 36-44 / 75$ & 6 & 83 & 11 & $\mathrm{Si}$ & 8.06 & 0.20 & - & 3.0 \\
\hline $44 / 45-68 / 69$ & 48 & 22 & 30 & SiCL & 7.96 & 0.00 & - & 2.9 \\
\hline $68 / 69-110$ & 94 & 2 & 4 & $\mathrm{~S}$ & 7.24 & 0.00 & - & 2.1 \\
\hline
\end{tabular}

Soil classification:

1) Gleyed regosol (Canadian Classification).

2) Aquent, if the colour of the lower horizons is ignored (U.S. Classification),

Otherwise it does not fit the system.

3) Juvenile Solonchak (USDA, 1938).

mapped across the Soviet Union by Kondovskaya (1967). Most of these regions have seasonal frost, while some areas of saline soils in Yakutia lie well within the limits of permafrost. The sulfate-dominated salinity is reported from Alaska (Krause and Wilde, 1966) and is also present at Kluane Lake. There are also large areas of sulfate-dominated groundwater reported from across the subhumid parts of the Prairie provinces (Geological Survey of Canada, 1967), indicating that this is likely to be the common type of salinization under natural conditions across this region.

Where irrigation occurs, secondary salinization is produced, the resulting salinity reflecting the composition of the irrigation waters as well as that of the local groundwater (Darab and Szabolcs, 1960; Harris, 1960; Kuryleva, 1962; Maianu, 1962, 1963, 1964; Obrejanu et al., 1963; Wilcox and Resch, 1963; Minashina, 1964; Zonn and Limachev, 1967; etc.). In Canada, this is also becoming a problem (e.g., van Schaik and Milne, 1963; Graveland, 1970; Chang et al., 1985) and will undoubtedly become more widespread as the irrigated land increases in area.
TABLE 11. Results of laboratory analysis of soil samples from Pit TC \#7, Slims River Delta

\begin{tabular}{|c|c|c|c|c|c|c|c|c|}
\hline \multirow[b]{2}{*}{ Depth $(\mathrm{cm})$} & \multicolumn{3}{|c|}{ Particle size (\%) } & \multirow[b]{2}{*}{ Texture } & \multirow[b]{2}{*}{$\mathrm{pH}$} & \multicolumn{3}{|c|}{$\begin{array}{c}\text { Electrical conductivity } \\
(\mathrm{mS} / \mathrm{cm})\end{array}$} \\
\hline & Sand & Silt & Clay & & & $28 / 6 / 85$ & $31 / 5 / 86$ & $6 / 8 / 87$ \\
\hline $0-3 / 5$ & 49 & 45 & 6 & $\mathrm{SiL}$ & 8.70 & 6.2 & 49.0 & - \\
\hline $3 / 5-10$ & 3 & 87 & 10 & $\mathrm{Si}$ & 8.52 & 4.25 & - & - \\
\hline $10-31$ & 6 & 84 & 10 & $\mathrm{Si}$ & 8.31 & 1.65 & 19.5 & 27.5 \\
\hline $31-43$ & 10 & 80 & 10 & SiL-Si & 8.44 & 1.25 & 22.5 & 40.1 \\
\hline $43-63$ & 2 & 90 & 8 & $\mathrm{Si}$ & 8.29 & 0.7 & 19.5 & 40.0 \\
\hline 63-90 & 62 & 34 & 4 & SL & 8.23 & 0.0 & - & 12.3 \\
\hline
\end{tabular}

Soil classification:

1) Gleyed regosol (Canadian Classification).

2) Salorthid or unclassifiable (U.S. Classification)

3) Solonchak (USDA, 1938).

In the case of the Slims River Delta, the main sources of the salts are the springs along the foot of the adjacent mountains (see Table 12). These springs discharge onto the surface of the delta from May to July, slowly drying up during the summer. Similar high-sulfate springs have been described by Krause and Wilde (1966) from the Russian Pass and Fort Yukon areas of Alaska, while similar groundwater seepages produce saline soils on the valley floor along the Tanana River Plain near Whitehorse (Scott Smith, pers. comm. 1985). Sodium-dominated salinity has been recorded from an area of 80000 ha on the Slave River Lowlands near Fort Simpson (Pringle et al., 1975). Thus the occurrences of saline soils known from the Prairie provinces extend northwestwards through the southwest Northwest Territories and southern Yukon Territory to central Alaska.

\section{Processes Involved in Actual Salinization}

The recent literature on the processes involved in producing saline soils in North America shows substantial diversity 
TABLE 12. Results of laboratory analysis of soil samples from Pit TC \#3, Slims River Delta

\begin{tabular}{|c|c|c|c|c|c|c|c|c|}
\hline \multirow[b]{2}{*}{ Depth $(\mathrm{cm})$} & \multicolumn{3}{|c|}{ Particle size (\%) } & \multirow[b]{2}{*}{ Texture } & \multirow[b]{2}{*}{$\mathrm{pH}$} & \multicolumn{3}{|c|}{$\begin{array}{l}\text { Electrical conductivity } \\
(\mathrm{mS} / \mathrm{cm})\end{array}$} \\
\hline & Sand & Silt & Clay & & & $5 / 7 / 85$ & $31 / 5 / 86$ & $6 / 7 / 87$ \\
\hline $0-9 / 15$ & 5 & 80 & 15 & SiL & 8.47 & 3.45 & 23.5 & - \\
\hline $9 / 15-26 / 29$ & 2 & 87 & 11 & $\mathrm{Si}$ & 8.37 & 0.35 & 1.5 & 6.25 \\
\hline $26 / 29-45$ & 6 & 76 & 18 & Sil & 8.40 & 0.2 & 2.5 & 4.75 \\
\hline $45-61$ & 6 & 81 & 13 & SiL & 8.37 & 0.15 & - & 2.60 \\
\hline $61-174$ & 53 & 42 & 5 & SL & 7.55 & 0.05 & - & 5.30 \\
\hline
\end{tabular}

Soil classification:

1) Gleyed regosol (Canadian Classification).

2) Closet to the aquents (current USDA system)

3) Weekly developed solonetz (USDA, 1938)

of opinion. High water tables are a well-accepted cause (e.g., van Schaik and Milne, 1963; Greenlee et al., 1968; Sommerfeldt and Oosterveld, 1977), especially when altered by irrigation (Graveland, 1970; Chang et al., 1985). Wilding et al. (1963) regarded weathering of sodium-bearing minerals as the cause of soluble sodium salts in solonetzic soils in Illinois. The downslope leaching of salts in groundwater from upslope was invoked by Peterson (1961) for producing solodizedsolonetz soils in Washington State, while Krause and Wilde (1966) noted the importance of saline springs in Alaska. Ballantyne (1978) and Peterson (1980) have cited instances where wind erosion and redeposition of salty material from salty playa lake beds have produced areas of saline soils by wind, and water has been invoked by Hadley and Rolfe (1955), Jordan et al. (1958), Munn and Boehm (1983) and Johnson et al. (1985) in South Dakota and Montana. However, as noted in the introduction, the role of seasonal frost seems to have been ignored.

In the case of the Slims River Delta, the level of the main groundwater table is obviously not a factor and the area is not under irrigation. Apart from minor wind erosion of the surface silts (Nickling, 1976, 1978), erosion is not a factor. However, the ground temperature data establishes that frost penetration into the soils of the deltas is about $4 \mathrm{~m}$ by spring. Thus, when the snow melts in late April or early May, there is a frozen barrier to downward percolation of the surface water and salts in the thawed layers of the soils. At the same time, more salts are added to the surface by runoff and by spring water from the adjacent mountains. The result is a saline, muddy layer that can only drain slowly down the very gentle gradients towards the river and lake. Evaporation quickly dries the ground surface, and salts are concentrated there by capillary action and further evaporation.

Although the soil is underlain by sands and sandy loams with a relatively high permeability, it is the end of June before the frozen layer becomes intermittent so that downward leaching is possible. By then the upper layers of the ground are fairly dry. The higher rainfall of July is usually sufficient to disperse the salinity through a greater depth within the soil (Figs. 7, 8), but it returns to the surface in the drier months of autumn. Should the rainfall in July be low, salinity will remain higher at the surface, but if the rainfall is unusually great, then there may be a significant leaching of the excess salts into the groundwater and into the river and lake.

The main methods of reducing the salinity appear to be by runoff of meltwater in the spring, by summer leaching by heavy rainfall after the seasonal frost has left the ground, and by blowing away of crystals of salts along with the fine surface silt loam during erosion of loess (Nickling, 1976, 1978). Further research should be carried out on the relative importance of these processes.

Freeze-up does not appear to cause any great redistribution of salts in the soils according to the available evidence. Thus there is still an ample supply of soluble salts in the upper soil horizons up to one kilometre from the springs at the foot of the mountains, so that highly saline soils are present as soon as the surface few centimetres thaw out in the spring.

The three- to fourfold variability in salinity from year to year on the Slims River Delta is intermediate between the twofold variation reported by Elovskaya (1964) from Yakutia in a region of continuous permafrost and the tenfold variability noted by Kovda (1947) from warmer climates in the southern U.S.S.R. in the only shallow, short-lived seasonal frost. This suggests that there may be less seasonal variability in salinity in the colder northern climates, but the variability from year to year will make mapping and predicting levels of salinity rather difficult. This needs to be taken into account in soil classification systems.

\section{Rate of Build-up of the Salinity on the Slims River Delta}

The build-up of salinity is impressive, considering that the delta must have formed in the last 300 years after the reversal of drainage along the Slims River Valley (Borns and Goldthwait, 1966). The size of the delta is reasonably consistent with the estimates of progradation of $17 \mathrm{~m}$ per year (Bryan, 1974) and would imply that the material in the delta at the transect formed about a century ago at the end of the last phase of Neoglaciation. The soils would be even younger, and despite wind erosion and flooding, a substantial accumulation of salts has taken place. The high winds and rain shadow effect have undoubtedly contributed to the presence of solonchaks on the delta ridges, while polygonal cracking is found in depressions. However, the dominance of sulfates over chlorides in the soils has tended to prevent the full development of the solonetz-solod soil sequence.

\section{Implications for Other Lowland Areas with Seasonal Frost}

As noted above, the Slims River Delta lies in a belt of land stretching from central Alaska to the Prairie provinces, where saline soils tend to develop on low-lying areas. The entire region, as well as substantial portions of the northern United States, also has deep seasonal frost that will tend to aid in the build-up of salts in the upper layers of the soil, given a suitable source of these salts in the area. Irrigation will tend to increase this trend unless steps are taken to flush the salts out of the upper layers of the soil in the latter part of the summer by additional applications of water and by drainage. Unfortunately this is not particularly compatible with harvesting crops, although it may be possible in hay fields. This salinization represents a major limitation to northern agriculture.

\section{Effects of Climatic Change}

The only climatic changes that will decrease the tendency to salinization are increased winter snowfall, increased late summer precipitation, or lower summer temperatures. Increased winter snowfall would provide more surface runoff 
and less winter frost penetration, while increased late summer precipitation would aid in leaching out the salts. Lower summer temperatures would decrease the tendency to build up salts in the surface of the soil, but this regime is the opposite of what is predicted by the proponents of the $\mathrm{CO}_{2}^{-}$ induced climatic changes. Salinization of the type studied here will become a serious problem, making it difficult to successfully move the agricultural belt in Canada northwards if this climatic warming occurs. Any available source of salts, e.g., springs (Krause and Wilde, 1966; this study) or irrigation waters (van Schaik and Milne, 1963; Graveland, 1970; Chang et al., 1985), will cause problems because the widespread deep seasonal frost will prevent leaching by melting snow in the spring. Similar problems will be encountered in the areas of saline soils in the regions of deep seasonal frost and permafrost in China and the Soviet Union (e.g., Yelovskaya, 1965). This will mean that it will be difficult to successfully move the agricultural belt northwards in Canada, China and the Soviet Union if this climatic warming occurs.

\section{CONCLUSIONS}

The saline soils of the Slims River Delta are an interesting case study of their formation on a new land surface since the end of the last Neoglacial event. The source of the salts appears to be the springs and seepage sites at the foot of the mountain slopes. The deep seasonal frost prevents leaching of the salts through the soil into the relatively permeable subsoil so that they tend to be concentrated at the surface in early summer as the soils dry out. Unless heavy late-summer rains occur, the salts remain in the surface soil and a significant build-up can be demonstrated with time. A three- to fourfold variation in salinity may occur from year to year, which is intermediate between the range found in areas of continuous permafrost and the saline soils of warmer climates.

The efflorescences are dominated by the hexahydrate of magnesium sulfate, while the associated clay mineral is sepiolite. The high sulfate content of the salts is probably the reason that the soils in the depressions have the morphology of solonetzic soils, yet the horizons remain reasonably friable. Solonchaks are widespread on the low ridges.

Vegetation distribution clearly indicates the approximate area of the saline soils, but the plant associations appear to be controlled more by soil moisture than salinity (see Table 7). There is considerable variation in the distribution and amount of salinity from year to year, and this is the probable reason for the species distribution of perennials merely indicating the approximate salinity distribution being reached in a given area in years of extreme salinity rather than actual values in a given year.

\section{ACKNOWLEDGEMENTS}

The field work was carried out with the financial help of NSERC Grant A-7483 and of Northern Training Grants to Denise Cook, Peter Hettstedt, Lynette Kirkham and Katherine O'Brian. Parks Canada suggested the study and provided logistical help. Dr. A.A. Levinson (Department of Geology, University of Calgary) analyzed the samples of efflorescence as well as one water sample, while Gerry Whitley (Water Resources, Department of Indian and Northern Affairs, Whitehorse) arranged for the water analyses of spring, river and lake waters of mutual interest. They were carried out in the Vancouver laboratories of Environment Canada. Healso provided the equipment for measuring the water level of the Slims River. Dr. G.W. Argus, of the National Museums of Canada, Ottawa, identified the samples of Salix spp. from the delta, while Mrs. K. Wilkinson identified the grasses. The determinations of several species were confirmed by the Herbarium at the Biosystematics Research Institute, Department of Agriculture, Ottawa.

\section{REFERENCES}

BALDWIN, M., KELLOGG, C.E., and THORP, J. 1938. Soil Classification. In: Soils and Man. 1938 Yearbook of Agriculture. Washington, D.C.: U.S. Government Printing Office. 999-1001.

BALLANTYNE, A.K. 1978. Saline soils in Saskatchewan due to wind deposition. Canadian Journal of Soil Science 58:107-108.

BARNETT, A.P. 1971. Hydrological Studies of the Slims River, Yukon Territory, Canada, June-August 1970. M.A. thesis, Department of Geography, University of Michigan.

BORNS, H.W., and GOLDTHWAIT, R.P. 1966. Late Pleistocene fluctuations of the Kaskawulsh Glacier, southwestern Yukon Territory, Canada. American Journal of Science 264:600-619.

BRYAN, M.C. 1974. Sublacustrine morphology and deposition, Kluane Lake. Icefield Ranges Research Publications, Scientific Results 4:171-187.

CANADA DEPARTMENT OF THE ENVIRONMENT. 1982. Monthly Record - Meteorological Observations in Canada. Vol. 67, Nos. 1-12, Part 2. Downsview, Ontario: Atmospheric Environment Service.

CANADA SOIL SURVEY COMMITTEE. 1978. The Canadian System of Soil Classification. Canada Department of Agriculture, Publication 1646. $164 \mathrm{p}$.

CHANG, C., KOZUB, G.C., and MacKAY, D.C. 1985. Soil salinity status and its relation to some of the soil and land properties of three irrigation districts in southern Alberta. Canadian Journal of Soil Science 65:187-193.

DARAB, K., and SZABOLCS, I. 1960. Types of secondary salinization of soils in the irrigated zones of the region of the great Hungarian plains. Transactions of the 7th International Congress of Soil Science 1:535-542

ELOVSKAYA, L.G. 1964. Saline soils of Yakutia. Transactions, 8th International Congress of Soil Science 2:819-825.

EL'SWAIFY, S.A., ARUNIA, S.S., and ABROL, I.P. 1983. Soil salinization: development of salt-affected soils. In: Carpenter, R.A., ed. Natural Systems for Development. London: Macmillan. 162-228.

ENVIRONMENT CANADA. 1979. Analytical Methods Manual. Ottawa: Water Quality Branch, Environment Canada.

FAHNESTOCK, R.K. 1969. Morphology of the Slims River. Icefield Ranges Research Publications, Scientific Results 1:161-172.

FOOTHILLS PIPELINES (YUKON) LTD. 1976. Environmental Statement. Vol. 5, B-1, Table 19

GEOLOGICAL SURVEY OF CANADA. 1967. Groundwater in Canada. Geological Survey of Canada, Economic Geology Report 24. Brown, I.C., ed. 228 p.

GLINKA, K.D. 1931. Treatise on Soil Science. Moskva-Leningrad: Gosudarstrennoe sel' skokhozyaistrennoe izadtel'stro. 4th ed. 612 p.

GRAVELAND, D.N. 1970. Migration of soluble salts in an irrigated field in relation to rainfall and irrigation. Canadian Journal of Soil Science 50:43-46.

GREENLEE, G.M., PAWLUK, S., and BOWSER, W.E. 1968. Occurrence of soil salinity in the dry lands of south-western Alberta. Canadian Journal of Soil Science, 48:65-75.

HADLEY, R.F., and ROLFE, B.N. 1955. Development and significance of seepage steps in slope erosion. Transactions of the American Geophysical Union 36:792-804.

HALLSWORTH, E.G., ROBERTSON, G.K., and GIBBONS, F.R. 1955. Studies in pedogenesis in New South Wales. VII. The 'gilgai' soils. Journal of Soil Science 9:169-185.

HARRIS, S.A. 1958. The gilgaied and bad-structured soils of Central Iraq Journal of Soil Science 8:1-34.

1959. The classification of gilgaied soils: some evidence from Northern Iraq. Journal of Soil Science 10:27-33. 130. 1960. Saline soils in the Kirkuk Plain. Journal of Soil Science, 2:116-

1983. Comparison of the climatic and geomorphic methods of predicting permafrost distribution in western Yukon Territory. In: Permafrost: 4th International Conference Proceedings. Washington: National Academy Press. 450-455.

1987. Altitude trends in permafrost active layer thickness, Kluane Lake, Yukon Territory. Arctic 40:179-183. 
HOEFS, M., McTAGGART-COWAN, I., and KRAJINA, V. 1975. Psychosociological analysis and synthesis of Sheep Mountain, southwest Yukon Territory, Canada. Syesis 8 (Supp. 1):125-228.

HORN, M.E., HALL, V.L., CHAPMAN, S.L., and WIGGINS, M.M. 1967. Chemical properties of the coastal alluvial soils of the Republic of Guinea. Soil Science Society of America Proceedings 31:108-114.

JOHNSON, W.F, MAUSBACH, M.J., GAMBLE, E.E., and NELSON, R.E. 1985. Natric horizons on some erosional landscapes in Northwestern South Dakota. Soil Science Society of America Journal 49:947-952.

JOHNSTON, G.H., ed. 1981. Permafrost Engineering Design and Construction. National Research Council of Canada. New York: John Wiley and Sons. $540 \mathrm{p}$

JORDAN, J.V., LEWIS, G.C., and FOSBERG, M.A. 1958. Tracing moisture movement and slickspot soils and radiosulfur. Part I. Transactions of the American Geophysical Union 39:446-450.

KELLER, L.P., MCCARTHY, J., and RICHARDSON, J.L. 1986. Mineralogy and stability of soil evaporites in North Dakota. Soil Science Society of America Journal 50:1069-1071.

KILMER, V.J., and ALEXANDER, L.T. 1949. Methods of making mechanical analyses of soils. Soil Science 68:15-24.

KONDOVSKAYA, N.I. 1967. Areas of present-day salt accumulations in U.S.S.R. soils. Soviet Soil Science 4:462-473.

KOVDA, V.A. 1947. Proiskhozhdeniye i regim zasolennikh pochv. MoscowLeningrad:Izd. An. SSR.

KRAUSE, H.H., and WILDE, S.A. 1966. Solonchak soils of Alaska. Soviet Soil Science 43-44.

KURYLEVA, N.I. 1962. The water and salt regime in soils of irrigated territories and its regulation. Trudy Bukhar Oblast opyt. s-kh. Stants. 1:5-57. In Russian.

MAIANU, A. 1962. The causes of secondary salinization in endyked irrigated soils. Academie Republique Populaire Problemey Agriculture 14(9):46-54. In Romanian.

1963. A study of the process of secondary soil salinization in terraced plots of rice: means of its prevention and control. Annals Inst. Cent. Cerc. Agriculture 30A (1962):215-235. In Romanian.

1964. Secondary soil salinization on step-located ricefields. Transactions 8th International Congress of Soil Science 2:827.

McQUAID, B.F., SCHUMACHER, B.A., and MILLER, B.J. 1987. The Solodic Subgroup: a proposed amendment to "Soil Taxonomy." Soil Science Society of America Journal 51:990-993.

MINASHIRA, N.G. 1964. Salinization and the necessity for reclaiming soils which were irrigated in ancient times in the zone of the Karakum canal. Pochvovedenie 1:9-21. In Russian.

MUNN, L.C., and BOEHM, M.M. 1983. Soil genesis in a Natrargid-Haplargid complex in northern Montana. Soil Science Society of America Journal 47:1186-1192.

NICKLING, W.G. 1976. Eolian sediment transport, Slims River Valley, Yukon Territory. Ph.D. thesis, Department of Geography, University of Ottawa. $246 \mathrm{p}$.

1978. Eolian sediment transport during dust storms. Slims River Valley, Yukon Territory. Canadian Journal of Earth Sciences 15:1069-1084.

OBREJANU, G., MAIANU, A., and ALBESCU, I. 1963. Experimental results on the prevention and control of secondary salinization of dammed and irrigated soils of the Lower Danube floodplain. Stiinta Sol 1:64-72. In Romanian
PETERSON, F.F. 1961. Solodized solonetz soils occurring in the uplands of the Palouse Loess. Ph.D. thesis, Washington State University, Pullman. 1980. Holocene desert soil formation under sodium salt influence in playa-margin environment. Quaternary Research 13:172-186.

PRINGLE, W.L., CAIRNS, R.R.,HENNIG, A.M.F., and SIEMENS, B. 1975. Salt status of some soils of the Slave River Lowlands in Canada's Northwest Territories. Canadian Journal of Soil Science 55:399-406.

RAYCHAUDHURI, S.P., and MURTHY, R.S. 1960. Genetic classifications of some saline-alkali soils of the Indo-Gangetic alluvium. Transactions, 7th International Congress of Soil Science 4:278-282.

RHOADES, J.D. 1976. Measuring, mapping and monitoring field salinity and water table depths with soil resistance measurements. FAO Soils Bulletin 31:69-109.

RIEGER, S. 1983. The genesis and classification of cold soils. New York Academic Press. 230 p.

SIGMUND, A.A.J., de. 1928. The classification of alkali and salty soils. Proceedings 1st International Congress of Soil Science 1:330-344.

SOIL SURVEY STAFF. 1975. Soil Taxonomy. Washington, D.C.: Soil Conservation Service, U.S. Department of Agriculture. Agriculture Handbook 436. $754 \mathrm{p}$.

SOKOLOVSKIY, S.P. 1967. Saline soils of Cuba and their melioration. Soviet Soil Science 3:334-344.

SOMMERFELDT, T.G., and OOSTERVELD, M. 1977. Soil salinity in an Alberta irrigation district as affected by soil and groundwater characteristics. Canadian Journal of Soil Science 57:21-26.

TEDROW, J.T.F. 1977. Soils of the polar landscapes. New Brunswick, New Jersey: Rutgers University Press. $639 \mathrm{p}$

UGOLINI, F.C. 1986. Pedogenic zonation in the well-drained soils of the arctic regions. Quaternary Research 26:100-120.

USDA. 1954. Diagnosis and improvement of saline and alkali soils. Richards, L.A., ed. Washington, D.C.: Soils and Water Conservation Research Branch, Agriculture Research Board. Handbook No. 60.

van EVERDINGEN, R.O. 1976. Geocryological terminology. Canadian Journal of Earth Sciences 13:862-867.

van SCHAIK, J.C., and MILNE, R.A. 1963. Salt accumulation in a glacial till soi in the presence of saline groundwater at shallow depths. Canadian Journal of Soil Science 43:135-140.

van VLIET-LANOË, B. 1988. Le rôle de la glace de segregation dans les formations superficielles de l'Europe de l'Ouest. Processus et Héritages, Tomes I, II. Thèse de Doctorat d'Etat, Université de Paris I, Sorbonne, Centre de Géomorphologie du C.N.R.S. 854 p.

WAHL, H.E., FRASER, D.B., HARVEY, R.C., and MAXWELL, J.B. 1987. Climate of the Yukon. Ottawa: Atmospheric Environment Service, Canadian Government Publishing Centre. 321 p.

WHITE, G.F. 1960. Science and the future of arid lands. Paris: UNESCO. $96 \mathrm{p}$. WILCOX, L.V., and RESCH, W.F. 1963. Salt balance and leaching requirement of irrigated lands. Washington, D.C.: U.S. Department of Agriculture. Technical Bulletin 1290.23 p.

WILDING, L.P, ODELL, R.T, FEHRENBACHER, J.B., and BEAVER, A.H 1963. Source and distribution of sodium in solonetzic soils in Illinois. Soil Science Society of America Proceedings 27:432-438.

YELOVSKAYA, L.G. 1965. Saline soils of Yakutia. Soviet Soil Science 4:355359.

ZONN, I.S., and LIMACHEV, N.S. 1967. Water-physical properties of the Euphrates valley soils. Soviet Soil Science 8:1080-1092.

APPENDIX A. Methods used to analyze the water samples in Table 3 at the groundwater laboratory, Environment Canada, Vancouver (courtesy of Howard Black) (for more details, see Environment Canada, 1979)

$p H$ : Method \#10301. Determination with glass and calomel electrodes using buffer solutions for calibration.

Specific Conductivity: Method \#02041. Specific conductance by conductivity using platinum electrodes and corrected to $25^{\circ} \mathrm{C}$.

Calcium: Method \#20101. E.D.T.A. titration with calibre 2 indicator after passing through a 0.45 micron filter paper. $\mathrm{NaOH}$ and indicator are added and titrated with standard E.D.T.A.

Magnesium: Method \#12108. Magnesium hardness calculated from the value of total hardness and calcium hardness.

Potassium: Method \#11103. Flame photometry with internal lithium standard on auto-analyzer. Calibrated with standard solutions.
Sodium: Method \#11103. Flame photometry with internal lithium standard on auto-analyzer. Calibrated with standard solutions. Chloride: Method \#17206. Calorimetric determination on autoanalyzer spectrophotometer using ferric nitrate and mercury thiocyanate. Filtered if necessary.

Sulfate: Method \#16306. Calorimetric determination on autoanalyzer spectrophotometer with barium chloride and methyl thymol blue.

Nitrate: Method \#07110. Calorimetric determination on an autoanalyzer spectrophotometer. Ammonium chloride and ammonium hydroxide to buffer to $\mathrm{pH} 8.5$, and passed through a column of copper-cadmium filings. 